NBER WORKING PAPER SERIES

\title{
CAPM FOR ESTIMATING THE COST OF EQUITY CAPITAL: INTERPRETING THE EMPIRICAL EVIDENCE
}

\author{
Zhi Da \\ Re-Jin Guo \\ Ravi Jagannathan \\ Working Paper 14889 \\ http://www.nber.org/papers/w14889 \\ NATIONAL BUREAU OF ECONOMIC RESEARCH \\ 1050 Massachusetts Avenue \\ Cambridge, MA 02138 \\ April 2009
}

We thank for helpful comments Bob Chirinko, Bob Dittmar, Bruce Grundy, Dermot Murphy, Ernst Schaumburg, Bill Schwert (the Editor), William Sharpe, Mike Sher, Mitchell Warachka, Hong Yan, Wei Yang, Jianfeng Yu, an anonymous referee, and seminar participants at Singapore Management University, National University of Singapore, Nanyang Technological University, University of Illinois - Chicago, University of British Columbia, 2008 Australian Competition and Consumer Commission Regulatory Conference, 2009 FIRS Conference, University of Minnesota macro-finance conference, 2009 WFA, and the 20th conference on Financial Economics and Accounting. The views expressed herein are those of the author(s) and do not necessarily reflect the views of the National Bureau of Economic Research.

NBER working papers are circulated for discussion and comment purposes. They have not been peerreviewed or been subject to the review by the NBER Board of Directors that accompanies official NBER publications.

(C) 2009 by Zhi Da, Re-Jin Guo, and Ravi Jagannathan. All rights reserved. Short sections of text, not to exceed two paragraphs, may be quoted without explicit permission provided that full credit, including (C) notice, is given to the source. 
CAPM for Estimating the Cost of Equity Capital: Interpreting the Empirical Evidence

Zhi Da, Re-Jin Guo, and Ravi Jagannathan

NBER Working Paper No. 14889

April 2009, Revised June 2011

JEL No. G00,G11,G12,G31

\begin{abstract}
$\underline{\text { ABSTRACT }}$
We argue that the empirical evidence against the Capital Asset Pricing Model (CAPM) based on stock returns does not invalidate its use for estimating the cost of capital for projects in making capital budgeting decisions. Since stocks are backed not only by projects in place, but also the options to modify current projects and undertake new ones, the expected returns on stocks need not satisfy the CAPM even when expected returns of projects do. We provide empirical support for our arguments by developing a method for estimating firms' project CAPM-betas and project returns. Our findings justify the continued use of the CAPM by firms in spite of the mounting evidence against it based on the cross-section of stock returns.
\end{abstract}

Zhi Da

University of Notre Dame 239 Mendoza College of Business

Notre Dame, Indiana 46556-5646

zda@nd.edu

Re-Jin Guo

Department of Finance

University of Illinois at Chicago

University Hall 2431, M/C 168

601 South Morgan

Chicago, IL 60607

rguo@uic.edu

\author{
Ravi Jagannathan \\ Kellogg Graduate School of Management \\ Northwestern University \\ 2001 Sheridan Road \\ Leverone/Anderson Complex \\ Evanston, IL 60208-2001 \\ and NBER \\ rjaganna@northwestern.edu
}




\section{Introduction}

The Sharpe (1964) and Lintner (1965) Capital Asset Pricing Model (CAPM) is the workhorse of finance for estimating the cost of capital for project selection. Whatever the criticism in the academic literature, it continues to be the preferred model in managerial finance courses, and managers continue to use it. Welch (2008) finds that about $75.0 \%$ of finance professors recommend using the CAPM to estimate the cost of capital for capital budgeting. A survey of CFOs by Graham and Harvey (2001) indicates that $73.5 \%$ of the respondents use the CAPM.

The primary empirical challenge to the CAPM comes from several well-documented anomalies. A variety of managed portfolios constructed using various firm characteristics earn very different returns on average from those predicted by the CAPM. ${ }^{2}$ Fama and French (1993) conjecture that two additional risk factors beyond the stock market factor used in empirical implementations of the CAPM are necessary to fully characterize economywide pervasive risk in stocks. Their three-factor model has received wide attention and has become the standard model for computing risk-adjusted returns in the empirical finance literature.

Almost all the anomalies documented apply to stock returns. Should that be a reason to refrain from using the CAPM to calculate the cost of capital for a project? We review the literature and provide new empirical evidence to argue that there is little direct evidence against using the CAPM to estimate a project's cost of capital. The particular model we

\footnotetext{
${ }^{2}$ Notable among the anomalies that challenge the validity of the CAPM are the findings that average returns on stocks are related to firm size (Banz, 1981), the earnings-to-price ratio (Basu, 1983), the book-to-market value of equity (BM) (Rosenberg, Reid, and Lanstein, 1985), the cash flow-to-price ratio, sales growth (Lakonishok, Shleifer, and Vishny, 1994), past returns (DeBondt and Thaler, 1985; and Jegadeesh and Titman, 1993), and past earnings announcement surprise (Ball and Brown, 1968). Many other studies confirm similar patterns in different datasets, including in international markets.
} 
consider is Ross's (1976) single-factor linear beta pricing model based on the stock index portfolio. We refer to this as the CAPM for convenience, following convention.

Most firms have the option to undertake, reject, or defer a new project, as well as the option to modify or terminate a current project. Therefore, we can look at a firm as a collection of current and future projects and complex options on those projects. McDonald and Siegel (1985) observe that managers should optimally exercise these real options to maximize a firm's total value. The resulting firm value will consist of both the net present values of the projects and the value of associated real options, which is determined by how the firm expects to exercise those options. Berk, Green, and Naik (1999) build on this insight to develop a model where the expected returns on all projects satisfy the CAPM, but the expected returns on the firm's stock do not. While the CAPM will assign the right expected returns to the primitive assets (projects), it will in general assign the wrong expected returns to options on those primitive assets. Gomes, Kogan, and Zhang (2003), Carlson, Fisher, and Giammarino (2004), and Cooper (2006) provide several additional insights in building on the Berk, Green, and Naik (1999) framework. ${ }^{3}$

We bring out the general intuition behind the failure of the CAPM in pricing options on primitive assets. This intuition comes from Dybvig and Ingersoll (1982) and Hansen and Richard (1987) in which a given stochastic discount factor, like the one corresponding to the CAPM, while assigning the right prices to a subset of assets, may assign the wrong prices to other assets. We first illustrate this intuition in a factor pricing example similar to that in Connor (1984). We then illustrate the impact of options in a numerical example that can be

\footnotetext{
${ }^{3}$ In related work, Bernardo, Chowdhry, and Goyal (2007) highlight the importance of separating the growth options from equity beta. Jagannathan and Wang (1996) argue that because of the nature of the real options vested with firms, the systematic risk of firms will vary depending on economic conditions, and the stock returns of such firms will exhibit option-like behavior.
} 
interpreted using the conditional CAPM of Jagannathan and Wang (1996). An econometrician using standard time series methods may conclude that the CAPM does not hold for firms with real options, even when the returns on such firms satisfy the CAPM in a conditional sense. When the sensitivity of firms' stock returns to economywide risk factors changes in nonlinear ways because of the presence of such real options, even when returns on individual primitive projects satisfy the CAPM, it may be necessary to use excess returns on certain managed portfolios (like the Fama and French (1993) SMB and HML factors) as additional risk factors to explain the cross-section of stock returns. If that is the case, it would be justifiable to use the CAPM for estimating the cost of capital for projects, even if the CAPM cannot explain the cross-section of average returns on various managed portfolios.

In general, both the equity risk premium and the equity beta of a firm will be complex functions of the firm's project beta and real option characteristics. If we project them on a set of variables capturing the features of real options using linear regressions, the residual risk premium and the residual beta will be option-adjusted, and will more closely resemble the underlying project risk premium and project beta. Consequently, the CAPM may work well on the option-adjusted risk premium and beta. ${ }^{4}$

We first provide support for the option-adjustment procedure and the CAPM with respect to the option-adjusted return and beta. We simulate a large cross-section of all-equityfinanced firms, each as a portfolio of a primitive asset (project) and a call option on the asset. While the CAPM works for the asset, in the presence of the option, it does not work for the

\footnotetext{
${ }^{4}$ Jagannathan and Meier (2002) discuss another reason why the CAPM may be useful for capital budgeting. They argue that organizational capital may be in limited supply in firms with talented managers who generate positive net present value (NPV) projects. Such firms will choose to implement only those projects with sufficiently large NPVs, as if they use a high hurdle rate by adding a large hurdle premium to their CAPM-based weighted average cost of capital. Jagananthan, Meier, and Tarhan (2011) find that while managers do use a significant hurdle premium, the CAPM-based cost of capital is also an important determinant of the hurdle rate they use for making capital budgeting decisions.
} 
firm as a whole. A cross-sectional regression of the firm risk premium on the firm beta produces a large intercept term, a very small slope coefficient, and an R-square close to zero, just as we would find in data. Once we option-adjust the firm's beta by making it orthogonal to a set of real option proxies (option moneyness, firm book-to-market ratio, and asset idiosyncratic volatility), however, the option-adjusted beta matches the underlying project beta very well, and explains a large portion of the cross-sectional variation in option-adjusted firm risk premium.

We also provide empirical evidence supporting the use of the CAPM for calculating the cost of capital of a project for a full sample of stocks in the US from 1970 through 2008. Although real options are not directly observable, we proxy them using three empirical variables. The first variable is the firm's book-to-market ratio (BM thereafter), a common proxy for growth options in the finance literature (see Smith and Watts, 1992, among others). Berk, Green, and Naik (1999) explicitly links BM to growth options. The second is the idiosyncratic volatility (Ivol). Cao, Simin, and Zhao (2008) and Bekaert, Hodrick, and Zhang (2010) establish a theoretical link between the growth options available to managers and the idiosyncratic risk of equity. The third is the firm's return on asset (ROA). Recently, Chen, Novy-Marx, and Zhang (2010) argue that ROA is a good empirical proxy for the marginal product of capital, which is related to the marginal expansion option as in the real option model of Abel, Dixit, Eberly, and Pindyck (1996).

We examine the performance of the CAPM for project cost of capital calculation using a two-stage cross-sectional regression. In the first stage, we regress both the stock excess return and the stock beta on the three real option proxies. The real options proxies are measured in excess of these measures of the market, and the regression has no intercept terms; such 
procedures ensure that the CAPM holds for the market exactly. The residual excess returns and betas are option-adjusted. In the second stage, we regress the option-adjusted excess return on the option-adjusted beta. While the stock beta is not significant in explaining the cross-sectional variation in average excess returns, the option-adjusted beta is very significant in explaining the cross-sectional variation in average option-adjusted excess returns. We correct the errors-in-variables problem in our cross-sectional regression that arises from estimation errors associated with the rolling-window betas (Jagannathan, Kim, and Skoulakis, 2010). After this correction, we find the regression slope coefficient on the option-adjusted beta to be closer to the actual market risk premium and the regression intercept to be much closer to zero, consistent with the prediction of the CAPM. The option-adjusted beta is related to but not exactly equal to the beta on the firm's asset-in-place. This is because a firm's beta is in general a complicated function of the asset-in-place beta and the beta of embedded options. A linear regression procedure will not do a perfect job in isolating the asset-in-place beta.

Finally, we investigate the impact of real option adjustment on several well-known crosssectional expected return anomalies. We find that real option adjustment alleviates or even drives out several anomalies related to long-term stock price mean reversion. These anomalies include the asset growth anomaly of Cooper, Gulen, and Schill (2008), the investment-related anomaly of Anderson and Garcia-Feijoo (2006), Xing (2008), and Chen, Novy-Marx, and Zhang (2010), and the long-term return reversal of DeBondt and Thaler (1985). The real option adjustment, however, has little impact on anomalies that are related to short-term return continuation such as price momentum (Jegadeesh and Titman, 1993) and earnings momentum (Chan, Jegadeesh, and Lakonishok, 1996). To the extent that such short-term price continuation typically does not persist beyond a few quarters and requires frequent portfolio 
rebalancing, it is probably less relevant for the cost of capital calculation for a typical project whose life usually extends beyond five years.

When we confine the analysis to a subsample of stocks after excluding stocks whose betas are likely to be measured with large errors, support for use of the CAPM beta in project cost of capital calculation becomes even stronger. For instance, the slope coefficient in the crosssectional regressions is almost the same as the historical average excess return on the stock market index, and the intercept term is insignificantly different from zero.

Determination of the cost of capital has been an important focus in finance. Fama and French make a convincing case that the CAPM fails to describe the cross-section of stock returns (Fama and French, 1992, 1996, 1997, 1999, 2004, and 2006). Indeed, most of the research in the asset pricing literature focuses on understanding the determinants of expected returns on stocks. ${ }^{6}$ Our primary interest, however, is in evaluating the empirical evidence against the use of the CAPM for project cost of capital calculations in making capital budgeting decisions.

We illustrate the impact of real options through two examples in Section 2, and also provide a more detailed review of the related literature. Section 3 describes a simple regression procedure to alleviate the effect of real options and a simulation example. Section 4 demonstrates the effectiveness of option-adjusted beta and presents evidence that supports use of the CAPM in project cost of capital estimation using empirical analysis. Section 5 concludes.

\footnotetext{
${ }^{5}$ Among many other related works, Ferson and Locke (1998) find that the great majority of the error in estimating the cost of equity capital using the CAPM is due to the risk premium estimate; Pastor and Stambaugh (1999) show that the cost of equity estimation can be improved in a Bayesian framework; Ang and Liu (2004) discuss a general approach for discounting cashflows with time-varying expected returns.

${ }^{6} \mathrm{We}$ refer readers interested in the broader asset pricing literature to the excellent surveys by Campbell (2003), Duffie (2003), Ferson (2003), and Mehra and Prescott (2003).
} 


\section{Examples}

Dybvig and Ingersoll (1982) and Hansen and Richard (1987) point out that a given stochastic discount factor (SDF thereafter), like the one corresponding to the CAPM, while assigning the right prices to a subset of assets, may assign the wrong prices to other assets. Treynor and Mazuy (1966), Henriksson and Merton (1981), Merton (1981), Dybvig and Ross (1985), Jagannathan and Korajczyk (1986), and Glosten and Jagannathan (1994) make related observations - that in an economy where the CAPM holds for stock returns, the returns on managed portfolios that have option-like features may not satisfy the CAPM. We use two examples to illustrate the intuition behind those observations, i.e., why the CAPM may price the expected returns on primitive projects but not those on options.

We first explain this intuition in a factor pricing example similar to that in Connor (1984). In this example, the CAPM may hold conditionally as well as unconditionally for a subset of assets but need not hold either conditionally or unconditionally for other assets. In the second numerical example, we show that this intuition can also be made clear using the observations in Jagannathan and Wang (1996), Gomes, Kogan, and Zhang (2003), and Zhang (2005), who show that the CAPM may not hold unconditionally even when it holds in a conditional sense.

\subsection{The CAPM in a factor economy of Connor (1984)}

Following Connor (1984), who derives an equilibrium version of Ross's (1976) Arbitrage Pricing Theory, consider an economy with $\mathrm{K}$ economywide pervasive factors, where the representative investor's marginal utility for end-of-period wealth is a function of only those pervasive factors. In such an economy, Connor (1984) shows that there is a unique SDF, that 
is, some nonlinear function of the pervasive factors that assigns the right prices to all assets. We will consider the special case where $K=1$; i.e., there is only one pervasive factor, and that is the return on aggregate wealth portfolio (or the market portfolio).

Now, following Connor (1984), consider a subset of assets (denoted as projects) whose returns have the linear factor structure:

$$
r_{i}=a_{i}+b_{i} r_{m}+\varepsilon_{i},
$$

where $r_{m}$ is the market return (all returns in this subsection are gross returns), and $E\left[\varepsilon_{i} \mid r_{m}\right]=0$. As a result, the slope coefficient $b_{i}$ (which we call the CAPM beta for convenience) can be computed by regressing $r_{i}$ on $r_{m}$. Let $M$ denote the unique SDF that prices all assets correctly. Recall that $M=f\left(r_{m}\right)$, i.e., $M$ is some nonlinear function of only $r_{m}$. The function $f$ is linear only under special circumstances (such as when investors have quadratic utility as shown in Dybvig and Ingersoll, 1982).

The economy may also include options whose returns do not have the linear factor structure. Nevertheless, we can still regress the option return on the market return and write:

$$
r_{o}=a_{o}+b_{o} r_{m}+\varepsilon_{o},
$$

where $\varepsilon_{o}$ satisfies $E\left[\varepsilon_{o} r_{m}\right]=0$ by definition of "regression," but $E\left[\varepsilon_{0} \mid r_{m}\right]$ is strictly different from 0 . In that case, without loss of generality, it should be possible to choose the option in such a way (i.e., there exists such an option since we are in a complete market economy) that $E\left[\varepsilon_{0} f\left(r_{m}\right)\right]=E\left[\varepsilon_{0} M\right] \neq 0$.

Since $M$ is a valid pricing kernel, we have:

$$
\begin{gathered}
E\left[M r_{m}\right]=1, \\
E\left[M r_{i}\right]=E\left[M\left(a_{i}+b_{i} r_{m}+\varepsilon_{i}\right)\right]=1 .
\end{gathered}
$$

The assumption $E\left[\varepsilon_{i} \mid r_{m}\right]=0$ implies $E\left[f\left(r_{m}\right) \varepsilon_{i}\right]=0$ or $E\left[M \varepsilon_{i}\right]=0$. Therefore we have: 


$$
a_{i} E[M]+b_{i}=1
$$

If a risk-free asset exists, then the risk-free rate satisfies:

$$
r_{f}=\frac{1}{E[M]}
$$

Substituting this expression for $r_{f}$ into $a_{i} E[M]+b_{i}=1$ gives: $a_{i}=r_{f}-r_{f} b_{i}$.

Note that by substituting this expression for $a_{i}$ into the expression for expected returns on any project $i$ whose return has a linear factor structure, we get:

$$
\begin{gathered}
E\left[r_{i}\right]=a_{i}+b_{i} E\left[r_{m}\right], \\
E\left[r_{i}\right]=r_{f}+b_{i} E\left[r_{m}-r_{f}\right],
\end{gathered}
$$

which gives the CAPM linear-beta-pricing relation for all assets, i, with returns that have a strict linear factor structure.

The expected return on the option, however, does not satisfy this CAPM relation. This is because when we price the option return using $M$, we have:

$$
E\left[M r_{o}\right]=E\left[M\left(a_{o}+b_{o} r_{m}+\varepsilon_{o}\right)\right]=1
$$

Since $E\left[M \varepsilon_{o}\right]=E\left[f\left(r_{m}\right) \varepsilon_{o}\right] \neq 0$, we have:

$$
\begin{gathered}
a_{o} E[M]+b_{o}=-E\left(M \varepsilon_{o}\right)+1, \\
a_{o}=r_{f}-r_{f} b_{o}-r_{f} E\left(M \varepsilon_{o}\right), \\
E\left[r_{o}\right]=-r_{f} E\left(M \varepsilon_{o}\right)+r_{f}+b_{o} E\left[r_{m}-r_{f}\right] .
\end{gathered}
$$

Thus the CAPM relation will not hold for the option expected return.

Note, however, that a CAPM-like single-beta relation will hold for all assets, including options that do not have linear factor structure when $r_{m}$ is replaced by the return on the asset whose payoff is identical to that of $M$ (such asset exists when the market is complete). However, the CAPM single beta relation (where beta is the regression slope coefficient of the 
return on the asset on the return on the market portfolio) will only hold for those assets that have a linear factor structure. ${ }^{7}$

\subsection{A numerical example and the conditional CAPM}

Now we present a numerical example in which the CAPM correctly prices all primitive projects but not the stock expected returns, and asset pricing anomalies such as size and bookto-market effects will arise. The example is consistent with several empirical regularities: (1) value stocks have higher expected returns than the market and have positive CAPM alphas; (2) growth stocks have lower expected returns than the market and have negative CAPM alphas; (3) value stocks have lower CAPM betas than growth stocks; (4) the equity risk premium is countercyclical; (5) value stocks are riskier than growth stocks when the expected risk premium is high; and (6) size and BM can describe cross-sectional variation in expected returns on stocks. The intuition behind these patterns can be understood in the context of the conditional CAPM.

This example and the first one illustrate that when a firm is endowed with real options, the CAPM will not explain its equity expected return, and anomalies such as size and BM effects can arise. The CAPM could still hold, however, for the primitive projects, and can be used to compute the costs of capital for projects.

\subsubsection{The economy}

For purpose of illustration, we consider an economy with a market risk premium of 5\% per year, an annual risk-free rate of $5 \%$, and a flat yield curve. There are three possible states at the end of the year: Up (probability: 25\%), Mid (probability: 50\%), and Down (probability:

\footnotetext{
${ }^{7}$ To see this more clearly, let $M^{*}$ denote the linear projection of $M$ on the set of returns that have a linear factor structure and let $P\left(M^{*}\right)$ denote the price of $M^{*}$. Then $M^{*} / P\left(M^{*}\right)-r_{f}=K\left(r_{m}-r_{f}\right)$ where $K$ is a constant, since $M^{*} / P\left(M^{*}\right)$ is the minimum second moment return on the mean variance return frontier generated by the returns that have a linear factor structure (see Hansen and Richard, 1987).
} 
$25 \%)$. The returns on the market portfolio in these three states are: $40.4 \%, 8.0 \%$, and $-16.3 \%$, respectively, translating to an expected return of $10.0 \%$ for the market portfolio.

A firm in this economy consists of multiple projects and one option. All projects are identical with an initial cost of $\$ 1.00$ which can be viewed as the book value. Once undertaken, each project pays out an expected perpetual annual cash flow of $\$ 0.20$. By assumption, the CAPM prices these projects, which all have a CAPM beta of 1, with an appropriate discount rate of $10 \%(5 \%+1 \times 5 \%=10 \%$ as predicted by the CAPM). The market value of each project is therefore $0.20 / 10 \%=\$ 2.00$.

The option can be one of two types: a value option (VO) or a growth option (GO) with the state-contingent payoffs:

\begin{tabular}{cccc}
\hline State & Probability & $\begin{array}{c}\text { VO } \\
\text { Payoff }\end{array}$ & $\begin{array}{c}\text { GO } \\
\text { Payoff }\end{array}$ \\
\hline Up & 0.25 & $\$ 0.949$ & $\$ 1.808$ \\
Mid & 0.50 & $\$ 0.949$ & $\$ 1.095$ \\
Down & 0.25 & $\$ 0.456$ & $\$ 1.095$ \\
\hline
\end{tabular}

\subsubsection{Prices and expected returns}

We assume no arbitrage opportunities exist, i.e., all SDFs that assign the right prices are strictly positive. Consider one such valid SDF, $M=[0.7313,0.8164,1.4454]$ across Up, Mid, and Down states. It can be verified that $E[M(1+R)]=1$ for the risk-free rate and the market return, meaning the SDF can price the risk-free asset and the market portfolio.

With the SDF, we can price the two options using E[M×payoff]. The results are summarized as follows: 


\begin{tabular}{ccccccccc}
\hline State & Prob & $\begin{array}{c}\text { State } \\
\text { Price } \\
(\mathrm{M})\end{array}$ & $\begin{array}{c}\text { Riskfree } \\
\text { Rate }\end{array}$ & $\begin{array}{c}\text { Market } \\
\text { Return }\end{array}$ & $\begin{array}{c}\text { VO } \\
\text { Payoff }\end{array}$ & $\begin{array}{c}\text { VO } \\
\text { Return }\end{array}$ & $\begin{array}{c}\text { GO } \\
\text { Payoff }\end{array}$ & $\begin{array}{c}\text { GO } \\
\text { Return }\end{array}$ \\
\hline Up & 0.25 & 0.7313 & $5.0 \%$ & $40.4 \%$ & $\$ 0.949$ & $30.7 \%$ & $\$ 1.808$ & $54.0 \%$ \\
Mid & 0.50 & 0.8164 & $5.0 \%$ & $8.0 \%$ & $\$ 0.949$ & $30.7 \%$ & $\$ 1.095$ & $-6.6 \%$ \\
Down & 0.25 & 1.4454 & $5.0 \%$ & $-16.3 \%$ & $\$ 0.456$ & $-37.1 \%$ & $\$ 1.095$ & $-6.6 \%$ \\
\hline Price & & & & & $\$ 0.726$ & & $\$ 1.173$ & \\
ER & & & $5.0 \%$ & $10.0 \%$ & & $13.8 \%$ & & $8.5 \%$ \\
CAPM Beta & & 0.00 & 1.00 & & 1.10 & & 1.14 \\
CAPM ER & & & $10.0 \%$ & & $10.5 \%$ & & $10.7 \%$ \\
\hline
\end{tabular}

Given the prices of these two options, we can compute their annual returns and expected returns. With the help of returns on any of the two options, the market is now complete, and it can be verified that $M$ is the unique SDF that prices all the assets in this economy. Since there are three states, the option payoffs cannot be replicated by trading only the market portfolio and the risk-free asset. The option return therefore does not satisfy the factor structure assumption $\left(E\left[\varepsilon_{o} \mid r_{m}\right]=0\right)$ discussed earlier so the CAPM relation does not apply to its expected return. This can be seen by computing options' covariances with the market and their CAPM betas. Although value option (VO) has a higher expected return (13.8\%) than the market while the growth option $(\mathrm{GO})$ has a lower expected return $(8.5 \%)$ than the market, the growth option actually has a higher CAPM beta.

Because of the higher CAPM beta, the CAPM will predict a higher expected return on the growth option $(10.7 \%)$ than on the value option (10.5\%). In other words, the CAPM, although perfectly explaining the expected returns on primitive projects in the economy, fails to explain the expected returns on these two options. As a result, the value option seems to outperform the market (it carries a positive CAPM alpha of $13.8 \%-10.5 \%=3.3 \%$ ) while the growth option seems to underperform the market (it carries a negative CAPM alpha of $8.5 \%-10.7 \%$ $=-2.2 \%)$. 


\subsubsection{The conditional CAPM}

The intuition behind these results can be made clearer using the conditional CAPM of Jagannathan and Wang (1996) or, more broadly, the results in Hansen and Richard (1987). The conditional CAPM interpretation adds additional economic insights on why the value option (VO) earns a higher expected return than the growth option (GO).

When we add an intermediate time period to the example, the one-period trinomial tree is expanded to be a two-period binomial tree. The two states on each node are associated with equal probability. The payoffs to an investment in the market portfolio (assuming an initial investment of \$1) are:

\begin{tabular}{|c|c|c|}
\hline $\mathrm{T}=0$ & $\mathrm{~T}=$ Six Months & $\mathrm{T}=$ One Year \\
\hline & & Up (UU): $\$ 1.404$ \\
\hline & $\mathrm{U}: \$ 1.200$ & \\
\hline \multirow[t]{3}{*}{$\$ 1.000$} & & Mid (UD, DU): $\$ 1.080$ \\
\hline & D: $\$ 0.900$ & \\
\hline & & Down (DD): $\$ 0.837$ \\
\hline
\end{tabular}

The risk-free rate in each six-month period is $1.05^{0.5}-1=2.47 \%$.

The immediate consequence of adding the intermediate state is that the market is now dynamically complete with only two assets: the market portfolio, and the risk-free asset, since the option payoff can now be replicated by trading these two assets dynamically. Both the value option and the growth option can now be priced using the standard no-arbitrage replication argument, which justifies the SDF given in Section 2.2.2 (see Rubinstein, 1976, among others). 


\begin{tabular}{|c|c|c|c|c|c|}
\hline \multicolumn{3}{|c|}{ Value Option (VO) } & \multicolumn{3}{|c|}{ Growth Option (GO) } \\
\hline $\mathrm{T}=0$ & $\begin{array}{l}\mathrm{T}=\mathrm{Six} \\
\text { Months }\end{array}$ & $\mathrm{T}=$ One Year & $\mathrm{T}=0$ & $\begin{array}{l}\mathrm{T}=\text { Six } \\
\text { Months }\end{array}$ & $\mathrm{T}=$ One Year \\
\hline & & $\$ 0.949$ & & & $\$ 1.808$ \\
\hline & $\$ 0.926$ & & & $\$ 1.390$ & \\
\hline \multirow[t]{3}{*}{$\$ 0.726$} & & $\$ 0.949$ & $\$ 1.173$ & & $\$ 1.095$ \\
\hline & $\$ 0.614$ & & & $\$ 1.069$ & \\
\hline & & $\$ 0.456$ & & & $\$ 1.095$ \\
\hline
\end{tabular}

Given the payoffs (and the implied returns) of both the market and the options, we can compute the values on both nodes $\mathrm{U}$ and $\mathrm{D}$ for the period from six months to one year:

\begin{tabular}{crrrrr}
\hline State & ER (Market) & Beta (VO) & ER (VO) & Beta (GO) & ER (GO) \\
\hline $\mathrm{U}$ & $3.5 \%$ & 0.00 & $2.5 \%$ & 1.90 & $4.4 \%$ \\
$\mathrm{D}$ & $6.5 \%$ & 2.97 & $14.4 \%$ & 0.00 & $2.5 \%$ \\
\hline
\end{tabular}

Note first that the expected return on the market going forward is higher following a negative market return in state (D), consistent with the fact that the risk premium is counter-cyclical. In addition, the CAPM works for both options conditionally (on each node). This is not surprising, as the option can be replicated by both the market and the bond, and the CAPM prices the expected returns on both assets (see Dybvig and Ross, 1985).

The value option has a higher expected return unconditionally because it has a higher beta in state $\mathrm{D}$, precisely when the market risk premium is high. This is highlighted by Jagannathan and Korajczyk (1986) and is the key insight of the conditional CAPM of Jagannathan and Wang (1996).

Are value stocks indeed riskier when the risk premium going forward is high? Some empirical evidence in the literature suggests the answer is yes. For example, Petkova and Zhang (2005) find that value betas tend to covary positively, and growth betas tend to covary negatively with the expected market risk premium, which offers at least a partial explanation 
for the value premium. ${ }^{8}$ Why are value stocks more risky when the expected risk premium is high? Zhang (2005) provides an elegant explanation within the framework of the neoclassical theory of investment. It is more costly for value firms to downsize their capital assets since they are typically burdened with more unproductive capital. As a result, value stocks' returns covary more with economic downturns when the expected risk premium is high. ${ }^{9}$

\subsubsection{Stock characteristics}

Despite the failure of the CAPM in pricing options, the book-to-market ratio and the size of the firm serve as two sufficient statistics for describing the expected returns of all firms in the economy. To see this, note that all firms in the economy have two components: (1) the assets-in-place component, which includes $I_{i}$ projects, and (2) the option component $\left(O_{i}=\mathrm{VO}\right.$ or GO). The market value or size of each firm is: $V_{i}=2 I_{i}+O_{i}$. The expected return of the firm is a weighted average of expected returns on these two components: $E R_{i}=2 I_{i} / V_{i} \times 10 \%+$ $O_{i} / V_{i} \times E R_{O}$. It can easily be verified that, whether a firm is endowed with the value option or the growth option, its expected return can be expressed as $20 \% \times B M+10 \% /$ Size. Therefore the expected return increases with BM and declines with Size. In addition, BM and Size explain the expected returns on all firms.

\footnotetext{
${ }^{8}$ Other recent studies on the conditional CAPM include Wang (2003), Ang and Chen (2007) and Gulen, Xing, and Zhang (2010). Similar evidence is provided in the context of the consumption CAPM by Lettau and Ludvigson (2001), Santos and Veronesi (2006), and Lustig and Van Nieuwerburgh (2005).

${ }^{9}$ Lewellen and Nagel (2006), however, argue that the variation in betas and the equity premium would have to be implausibly great for the conditional CAPM to explain the size of the value premium. Lewellen and Nagel (2006) use high-frequency returns in their empirical analysis. Chan, Hameed, and Lau (2003) demonstrate that price and return may be driven in part by factors unrelated to fundamental cash flow risk. Such factors, together with liquidity events, may contaminate the estimation of beta at higher frequencies (see Pastor and Stambaugh, 2003). Bali, Cakici, and Tang (2009) and Bauer, Cosemans, Frehen, and Schotman (2009) improve the crosssectional performance of the conditional CAPM by using more efficient estimation techniques. Kumar, Srescu, Boehme, and Danielsen (2008) and Adrian and Franzoni (2008) demonstrate that once the estimation risk or parameter uncertainty associated with beta and risk premium are accounted for, the conditional CAPM will have significantly more cross-sectional explanatory power and may explain the value premium after all.
} 
Firms with the value option resemble value stocks. These firms have more assets-in-place, and because the value option is cheaper, value stocks are associated with higher BM. Because the value option has a higher expected return and positive CAPM alpha, so will the value stocks. Firms with the growth option resemble growth stocks. Unlike value stocks, growth stocks have lower BMs, lower expected returns, and negative CAPM alphas.

Why do characteristics such as BM and size describe cross-sectional return variations? The key intuition follows from Berk (1995). Given expectations about future payoffs, market value must be correlated with systematic risk across stocks. In our numerical example, BM summarizes the firm's risk relative to the scale of its asset base, and size describes the relative importance of assets-in-place and the option.

Other work combines this intuition with key insights from the real options literature pioneered by McDonald and Siegel (1985) in linking firm-specific investment patterns, valuation, and expected returns. A seminal paper by Berk, Green, and Naik (1999) studies the implications of the optimal exercise of real investment options. In their model, investment opportunities with low systematic risk are attractive to the firm; making such investments increases firm value and reduces the average risk of the firm. Consequently, the expected return of the firm is dynamically linked to price-based characteristics such as BM and size. Gomes, Kogan, and Zhang (2003) show that these results continue to hold in a general equilibrium setting as well. Size and BM, correlated with true conditional betas in their model, help to explain stock returns in the cross-section, especially when true betas are measured with error.

Carlson, Fisher, and Giammarino (2004) model the optimal dynamic investment behavior of monopolistic firms facing stochastic product market conditions. Their approach is similar 
in spirit to Berk, Green, and Naik (1999), except that they also introduce operating leverage, reversible real options, fixed adjustment costs, and finite growth opportunities. They show that the $\mathrm{BM}$ effect can arise even if there is no cross-sectional dispersion in project risk, as BM summarizes market demand conditions relative to invested capital.

Zhang (2005) demonstrates in an industry equilibrium model that the firm's optimal investments, together with asymmetry in capital adjustment costs and the counter-cyclical price of risk, can generate the BM effect. This is because value firms have difficulty disinvesting, making them more risky in bad times when the market risk premium is high. On the other hand, Cooper (2006) develops a dynamic model that allows the BM to be informative of the deviation of a firm's actual capital stock from its target. As a firm becomes distressed, book value remains constant, but market value falls, resulting in higher BM. Going forward, its extra installed capacity allows it to expand production easily without new investment, making its payoff more sensitive to aggregate shocks and its equity more risky. Empirically, Anderson and Garcia-Feijoo (2006) and Xing (2008) together provide supporting evidence that the investment dynamics of a firm drive the BM effect. More recently, Liu, Whited, and Zhang (2009) show that the dispersion in investment-to-capital between value and growth firms is the main driving force of the BM effect.

\section{The CAPM and the real option adjustment}

More generally, both the equity risk premium and beta will be functions of the project beta and other variables capturing real option effects. Assume that these functions can be linearized around the values of the market portfolio with small errors: 


$$
\begin{aligned}
& \mu_{i}=f\left(\mu_{i}^{p}, O P_{i}\right)=f\left(\mu_{M}^{p}, O P_{M}\right)+f_{1}\left(\mu_{i}^{p}-\mu_{M}^{p}\right)+f_{2}{ }^{\prime}\left(O P_{i}-O P_{M}\right)+\varepsilon_{i}, \\
& \beta_{i}=g\left(\beta_{i}^{p}, O P_{i}\right)=g\left(\beta_{M}^{p}, O P_{M}\right)+g_{1}\left(\beta_{i}^{p}-\beta_{M}^{p}\right)+g_{2}{ }^{\prime}\left(O P_{i}-O P_{M}\right)+\eta_{i},
\end{aligned}
$$

where $\mu_{i}$ and $\beta_{i}$ are the equity risk premium and the equity CAPM beta on stock $i ; \mu_{i}^{p}$ and $\beta_{i}^{p}$ denote the project risk premium and the project CAPM beta on stock i; and $O P_{i}$ represents the vector of variables that captures the effect of real options. Subscript $M$ denotes the market portfolio. By construction, $f\left(\mu_{M}^{p}, O P_{M}\right)=\mu_{M}$ and $g\left(\beta_{M}^{p}, O P_{M}\right)=\beta_{M}=1$. While the CAPM may fail to explain the equity risk premium $\left(\mu_{i} \neq \beta_{i} \mu_{M}\right)$ because of the presence of real options, it may work for projects themselves $\left(\mu_{i}^{p}=\beta_{i}^{p} \mu_{M}\right)$. The linearization thus suggests that if we remove the real option effects (terms involving $O P_{i}$ ) from $\mu_{i}$ and $\beta_{i}$, the residual (or real option-adjusted) equity risk premium and beta should generally satisfy a linear relation (subject to linearization errors).

Cross-sectional regressions (without the constant) can be used to remove the effect of $O P_{i}$ from $\mu_{i}$ and $\beta_{i}$ :

$$
\begin{aligned}
& \mu_{i}=a^{\prime}\left(O P_{i}-O P_{M}\right)+\mu_{i}^{O A}, \\
& \beta_{i}=b^{\prime}\left(O P_{i}-O P_{M}\right)+\beta_{i}^{O A} .
\end{aligned}
$$

The residuals, $\mu_{i}^{O A}$ and $\beta_{i}^{O A}$, can be viewed as the option-adjusted equity risk premium and the equity CAPM beta on stock $i$ and in that case we should expect $\mu_{i}^{O A} \propto \beta_{i}^{O A}$.

Since the market index portfolio is a value-weighted average of all stocks, if we take the cross-sectional (value-weighted) average of the option-adjusted equity risk premium and beta across all stocks, we have: 


$$
\begin{aligned}
& \mu_{M}=\overline{\mu_{i}}=\overline{\mu_{i}^{O A}}, \\
& \beta_{M}=\overline{\beta_{i}}=\overline{\beta_{i}^{O A}} .
\end{aligned}
$$

Since $\beta_{M}=1$ by construction, $\overline{\mu_{i}^{O A}}=\overline{\beta_{i}^{O A}} \times \mu_{M}$, which in turn implies:

$$
\mu_{i}^{O A}=\beta_{i}^{O A} \mu_{M}
$$

This constitutes the main testable hypothesis of our work: the option-adjusted CAPM beta explains the cross section of option-adjusted equity returns. We test this hypothesis first using simulation analysis.

\subsection{Simulation evidence}

In a simulation exercise to evaluate the effect of real options on expected firm stock returns and the performance of the CAPM, we consider a large cross-section of all-equityfinanced firms. Each firm consists of one primitive asset (project) and a call option on the asset. The assets differ in their CAPM beta $\left(\beta_{i}^{p}\right)$ and idiosyncratic volatility $\left(\right.$ Ivol $\left._{i}\right)$. For simplicity, we assume that all assets are associated with a book value of $\$ 1$ and a market value of $\$ 1$ and that the expected return on the primitive asset satisfies the CAPM.

All call options expire in one year and differ in their moneyness $\left(k_{i}\right)$. We assume that the call option can be priced using the standard Black-Scholes (1973) model. The cross-sectional variation in the call prices is therefore driven by three parameters: $k_{i}, I v o l_{i}$, and $\beta_{i}^{p}$, and the last two parameters jointly determine the volatility of the asset $\left(\sigma_{i}^{2}=\left(\beta_{i}^{p} \sigma_{M}\right)^{2}+I v o l_{i}^{2}\right)$. The call price then determines $w_{i}$, or the weight of the option as a percentage of the total value of the firm $i$. More precisely, $w_{i}=I_{i} O_{i} /\left(1+I_{i} O_{i}\right)$, where $I_{i}$ is equal to $1(-1)$ if firm $i$ is taking a 
long (short) position in the call option, and $O_{i}$ denotes the option value. In this simple economy, the book-to-market ratio (BM) of the firm perfectly reveals its option weight $\left(B M_{i}=\frac{1}{1+I_{i} O_{i}}=1-w_{i}\right)$. The expected return on the firm does not satisfy the CAPM because there is a call option. Overall, the risk premium on firm $i\left(\mu_{i}\right)$ is a value-weighted average of the risk premium on the project $\left(\mu_{i}^{p}\right)$ and the option $\left(\mu_{i}^{O}\right)$ :

$$
\mu_{i}=\left(1-w_{i}\right) \mu_{i}^{p}+w_{i} \mu_{i}^{O}=\left(1-w_{i}\right) \beta_{i}^{p} \mu_{M}+w_{i} \mu_{i}^{O} .
$$

We generate the cross-section of firms by choosing the parameter values as follows (on an annual basis): a market risk premium $\left(\mu_{M}\right)$ of $8.00 \%$; a market risk-free rate of $1.00 \%$; a market volatility of 0.20 (on the $\log$ market return); values for $k_{i}$ from 0.75 to 1.25 in increments of 0.05 at a time, values for $I v o l_{i}$ from 0.10 to 0.70 in increments of 0.10 at a time; and values of the primitive project beta $\left(\beta_{i}^{p}\right)$ from 0 to 2 in increments of 0.10 at a time. Finally, for each firm with a short position in a call option, we also generate two otherwise identical firms, each with a long position in the same option so options are in positive net supply overall.

For each firm we can compute the risk premium $\left(\mu_{i}\right)$ and the CAPM beta $\left(\beta_{i}\right)$ of the stock numerically. ${ }^{10}$ Finally, the CAPM beta is measured with errors, and the measurement error is drawn from a normal distribution of zero mean and a variance of 0.01 .

As the CAPM cannot price the expected return on the option component, it will not be able to price the expected return on the firm either. Panel A of Figure 1 confirms this result. When we plot the firm's expected return $v s$. its CAPM betas, we do not observe a significant

\footnotetext{
${ }^{10}$ Specifically, for each firm, we use Monte Carlo simulation to simulate 10,000 possible project payoffs at the end of the year. For each project payoff, we compute the corresponding option payoff. The expected payoffs are computed as averages across all 10,000 paths. The covariance between the firm return and the market return and the beta can also be computed using these 10,000 realizations.
} 
positive relation as would be predicted by the CAPM. In fact, if we run a cross-sectional regression of firm expected return on firm CAPM betas, we confirm the well-documented failure of the CAPM to explain the cross-sectional variation in equity risk premium. First, the slope coefficient, which can be interpreted as the market risk premium, is only $2.04 \%$, which is way below the assumed value of $8.00 \%$. Second, when the risk premium estimate is biased toward zero, the intercept term is likely to be positive and significant. This is exactly what we find. The intercept term is $7.00 \%$ with a t-value of about 24.40 . Finally, the regression Rsquare is lower than $2.00 \%$.

As the CAPM holds on the primitive projects by construction in our simulation, the failure of the CAPM to predict firm returns should not invalidate its use for the purpose of project cost of capital calculation. Our main hypothesis posits that the CAPM should hold approximately for the option-adjusted equity risk premium and beta, and we test that in our simulated sample.

The cross-sectional variation in real option effects in our example can be fully captured by three parameters: the book-to-market ratio $\left(B M_{i}\right)$, the moneyness of the call option $\left(k_{i}\right)$, and the idiosyncratic volatility $\left(I v o l_{i}\right)$. Therefore, the option proxies $\left(O P_{i}\right)$ in this example are a vector of cross-sectionally demeaned $\left[B M_{i}, k_{i}, \operatorname{Ivol}_{i}\right]$.

We remove the option effects from the firm CAPM beta by regressing it on the option proxies in a cross-sectional regression with no constant. The residual or the option-adjusted beta $\left(\beta_{i}^{O A}\right)$ should therefore capture the project CAPM beta. We verify this in Panel B of Figure 1. When plotted together, the project beta $\left(\beta_{i}^{p}\right)$ lines up quite well with the optionadjusted beta $\left(\beta_{i}^{O A}\right)$. When we regress $\beta_{i}^{p}$ on $\beta_{i}^{O A}$, we get an R-square almost of $90.00 \%$ and 
a slope of 0.91 . Despite the nonlinear nature of the option effect, a simple linear regression seems to be quite successful in removing option effects from the firm beta and recovering the project beta.

In addition, we regress the firm risk premium $\left(\mu_{i}\right)$ on the option proxies in the crosssection with no constant to obtain the option-adjusted firm risk premium $\left(\mu_{i}^{O A}\right)$. The optionadjusted risk premium should capture the risk premium on the project. Our main hypothesis predicts that $\mu_{i}^{O A}$ will be equal to the product of the option-adjusted beta and the market risk premium, or $\mu_{i}^{O A}=\beta_{i}^{O A} \mu_{M}$. Panel $\mathrm{C}$ of Figure 1 provides supporting evidence for the hypothesis. We find that $\mu_{i}^{O A}$ is clearly positively related to $\beta_{i}^{O A}$. When we regress $\mu_{i}^{O A}$ on $\beta_{i}^{O A}$, we find a slope coefficient of $8.10 \%$, quite close to the assumed market risk premium of $8.00 \%$. At the same time, the intercept term is $-0.04 \%$, not significantly different from zero. In other words, the CAPM performs better once the option effects are removed with a simple regression procedure. Finally, the R-square is also much higher at $50.5 \%$. The R-square is not equal to 1 for several reasons. First, linear approximation errors affect both $\mu_{i}^{O A}$ and $\beta_{i}^{O A}$. Second, beta is assumed to be measured with error.

\section{The CAPM and project cost of capital: empirical analysis}

For our empirical analysis, we conduct monthly Fama-MacBeth (1973) cross-sectional regressions at the individual stock level with the Newey-West (1987) correction using a lag of 36. Each month, we regress monthly stock excess return (over the risk-free rate) on betas and 
stock characteristics that are measured using the most recent return and accounting data available to investors.

\subsection{Sample and variable definitions}

We start with firms covered by CRSP with common shares outstanding over 1970-2008, with the exclusion of penny stocks (with prices lower than \$5), and firms listed for less than three years. For each sample firm, the beta estimates are calculated as the slope coefficients of the CAPM regressions; while Beta_MKT, Beta_SMB, and Beta_HML are computed as the slope coefficients of the Fama-French three-factor regressions, both using the prior 60 months of return records from CRSP. ${ }^{11}$

Two return anomaly variables are constructed using the CRSP data: medium-term price momentum (Momt) as the cumulative monthly stock return of $[\mathrm{t}-13, \mathrm{t}-2]$, and long-term return reversal (Lret) as the cumulative monthly stock returns of [t $-60, t-13]$, prior to month $t$. Monthly idiosyncratic volatility (Ivol) in month $t$ is computed following the procedure in Ang, Hodrick, Xing, and Zhang (2006).

Our CRSP sample is further intersected with COMPUSTAT data where accounting information is available. We require a minimum six-month gap in matching the accounting data of calendar year $t-1$ to monthly return data of calendar year $t$ to ensure that the accounting information is available to market investors. We construct a number of variables using information available from COMPUSTAT files. BE is book value (in millions) as the

\footnotetext{
${ }^{11}$ Hoberg and Welch (2007) argue that investors may be slow in adjusting to recent changes in market risk, and recommend the use of aged beta. For this reason, we also examine aged betas (the CAPM beta estimated using [t - 85, $\mathrm{t}$ - 25] five-year rolling windows after skipping the most recent two years) and find them to produce similar results in the cross-sectional regressions.
} 
sum of stockholders' equity, deferred tax, investment tax credits, and convertible debt, minus the liquidation value of preferred stocks (Fama and French, 1992, 1993). BM is the ratio of BE over firm market capitalization measured as of the most recent June. ROA is the ratio of quarterly earnings scaled by the one-quarter-lagged asset in the prior quarter. The asset growth rate (Ast_gw) is calculated as the year-on-year percentage change in total assets (Cooper, Gulen, and Schill, 2008), while investment-to-capital ratio (Inv) is the annual change in gross property, plant, and equipment scaled by the lagged book value of assets (Chen, Novy-Marx, and Zhang, 2010). Earnings surprise (Sue) is computed using the difference in quarterly earnings in the $[t-3, t-6]$ window and the corresponding value announced 4 quarters ago scaled by the standard deviation of the corresponding earnings change over the previous 8 quarters prior to return measurement in month $t$ (Chan, Jegadeesh, and Lakonishok, 1996). Table 1 defines all the variables.

We focus on BM, Ivol, and ROA as our empirical real option proxies. BM is a common proxy for growth options in the finance literature (see Smith and Watts,1992, among others). The choice of Ivol is motivated by Cao, Simin, and Zhao (2008) and Bekaert, Hodrick, and Zhang (2010), which establish a theoretical link between growth options available to managers and the idiosyncratic risk of equity. Finally, Chen, Novy-Marx, and Zhang (2010) argue that ROA is a good empirical proxy for the marginal product of capital, which is related to the marginal expansion option as in the real option model of Abel, Dixit, Eberly, and Pindyck (1996). The choices of these three real option proxies are consistent with the simulation example in Section 3.1.

Table 2 reports pairwise correlations among our empirical variables. Several interesting patterns emerge. First, asset growth (Ast_gw), investment-to-capital ratio (Inv), and past long- 
term return (Lret) are highly correlated with one another, suggesting that those anomalies are related, and all seem to capture a long-term return reversal pattern. These three variables are also significantly correlated with $\mathrm{BM}$. To the extent that $\mathrm{BM}$ proxies for the real option, these correlations suggest that asset growth, investment-related, and long-term reversal anomalies could be related to real option features and thus may be partially alleviated if we control for BM in our option adjustment. Second, not surprisingly, earnings surprise (Sue) and mediumterm price momentum (Momt) are positively correlated, and they are both correlated with ROA, suggesting that earnings and price momentum may be alleviated if we control for ROA in our option adjustment.

Our final sample consists of a panel of monthly stock observations with non-missing real option proxies (BM, Ivol, ROA) from July 1970 through June 2008. There are on average 2,087 stocks each month. We denote this as our full sample. We also consider a subsample where we further eliminate stocks whose CAPM betas are likely to be estimated with large errors. We use two filters for this purpose. First, we exclude stocks that do not have complete five-year data to estimate betas. Second, we exclude stocks whose CAPM betas are extreme (below the 5th percentile or above the 95th percentile in the cross-section). The second filter is similar to what Mamaysky, Spiegel, and Zhang (2008) use in their analysis of mutual fund performance persistence. Altogether, these two filters remove about $14.6 \%$ (or $5.3 \%$ by market capitalization) of stocks from our full sample. Our subsample thus includes about 1,783 stocks per month on average.

\subsection{Cross-sectional regression analysis: full sample}


When there are real options associated with the primitive projects undertaken by the firm, both equity returns and equity betas are complicated functions of these real options, and the CAPM may not hold. Table 3 confirms the well-documented failure of the CAPM beta to explain the cross-sectional variation in returns. In Model 1, when we regress monthly individual stock excess return (in excess of the risk-free rate) on the CAPM beta, we get a slope coefficient very close to zero and a huge intercept term (78 basis points per month or $9.36 \%$ per year).

Models 2-6 confirm the presence of several well-known asset pricing anomalies in our sample. For example, firms with higher asset growth rates are associated with lower stock returns (asset growth anomaly, see Cooper, Gulen, and Schill, 2008); firms with higher investments are associated with lower stock returns (investment-related anomaly; see Anderson and Garcia-Feijoo, 2006; Xing, 2008; and Chen, Novy-Marx, and Zhang, 2010); stocks with higher long-term past returns are associated with lower returns (long-term reversal; see DeBondt and Thaler, 1985); stocks with higher returns in the last year have higher current returns (price momentum; see Jegadeesh and Titman, 1993); and stocks with positive earnings surprises have higher returns (earnings momentum; see Bernard and Thomas,1990). The CAPM beta is not significant at all in the presence of these anomalies.

Models 7-12 add the Fama-French three factor betas estimated using the standard fiveyear $[t-60, t-1]$ rolling window. While the HML factor beta becomes significant, the MKT factor beta remains insignificant and is associated with a close-to-zero risk premium. In addition, all five anomalies remain to be significant after the inclusion of two additional SMB and HML factor betas. 
Under our main hypothesis, if the failure of the CAPM on equity return is driven by real options, then removing the effect of real options from equity returns and betas should improve the performance of the CAPM. We follow the procedure described in Section 3 to conduct real option adjustment using a cross-sectional regression. In the first-stage regression, we regress the monthly (excess) stock return or the factor loadings (including the CAPM beta) on the three real option proxies (BM, Ivol, and ROA). All three variables are measured in terms of the excess over their counterparts for the market portfolio, and the regression has no intercept term. These procedures ensure that the CAPM relation holds for the market portfolio. The residuals from these regressions are the option-adjusted (excess) returns and optionadjusted betas. Given the fact that true real options, which are not directly observable, affect both returns and betas in highly complicated and nonlinear fashion, our simple regression approach may not fully remove real option effects. Yet to the extent that our real option proxies correlate with the true real options, the option-adjusted (excess) returns and optionadjusted betas from the first-stage regression should more closely resemble the risk premium and betas of the underlying primitive projects. If so, the CAPM should perform better after real option adjustments.

Table 4 reports results of the regression analysis in Table 3 but after the first-stage real option adjustments. In Model 1, we find the option-adjusted CAPM beta becomes significantly and positively related to the option-adjusted (excess) stock return. The slope coefficient is 42 bps per month (or $5.04 \%$ per year with a t-value of 3.11 ). In addition, the intercept term drops from 78 bps per month in Table 3 to 20 bps per month (or $2.40 \%$ per year), which is still significant $(\mathrm{t}-\mathrm{value}=3.14)$. 
Models 2-6 find the option-adjusted CAPM beta to be still highly significant (with tvalues usually above 2.6) even in the presence of the anomaly variables. Interestingly, the option-adjusted CAPM beta helps to weaken or even drive out several anomalies that are associated with long-term stock price mean reversion (Ast_gw, Inv, and Lret). For instance, after real option adjustment, the t-value associated with asset growth (Ast_gw) drops from 3.79 (in Table 3) to -2.34. Furthermore, investment-to-capital ratio (Inv) and past long-term return (Lret) become insignificant with t-values of -1.49 and -0.94 , respectively. This result is consistent with recent findings by Cooper and Priestley (2010), which suggest that firms' real options are likely driving the asset growth and investment-related anomalies. On the other hand, the real option adjustment has little impact on anomalies that are related to short-term return continuation. Both price and earnings momentum (Momt and Sue) remain highly significant. Additional unreported diagnostic tests confirm that both anomalies, at monthly frequency, are driven by components in Momt and Sue that are orthogonal to ROA. To the extent that short-term price continuation typically does not persist beyond a few quarters and requires frequent portfolio rebalancing, it is probably less relevant for the cost of capital calculation for a project whose life usually goes beyond five years. Models 7-12 again include the Fama-French three factor betas after the real option adjustment. The CAPM beta now drives out the factor loading on HML in explaining option-adjusted stock returns.

Our analysis so far suffers from the standard errors-in-variables problem as the time-series estimation of betas introduces measurement errors. Kim (1995) shows that the problem leads to a lower risk premium estimate and a higher intercept estimate in the cross-sectional regression, potentially explaining why we find that the slope coefficient is smaller than the market risk premium, and the intercept term is significantly different from zero. Following 
Jagannathan, Kim, and Skoulakis (2010), we directly correct the biased cross-sectional regression estimates for the errors-in-variables problem. The details of the correction are presented in the Internet Appendix. The bias-corrected regression coefficients and their tvalues are reported in Table 5.

A comparison of the results in Table 5 and those in Table 4 shows that bias correction in general increases the slope estimates on the CAPM beta and reduces the intercept estimates. For example, in Model 1, a single CAPM beta receives a slope estimate of 53 bps per month (or $6.36 \%$ per year), closer to the historical annual market risk premium of about $8.00 \%$ in the US. In fact, the slope coefficient of $6.36 \%$ per year is not significantly different from $8.00 \%$. In addition, the intercept term drops to 14 bps (or $1.68 \%$ per year) and becomes less significant $(\mathrm{t}$-value $=2.45)$. With the Fama-French three factor model (Model 7), the intercept term becomes even smaller at 6 bps per month (or $0.72 \%$ per year).

Figure 2 demonstrates the effect of option adjustment on selected portfolios. We compare the results of the portfolio average annualized excess returns plotted against portfolio average betas (left-hand panel); with those of the portfolio average option-adjusted excess returns against portfolio average option-adjusted betas (right-hand panel). The regression estimates are presented below the plots. In Panel A, based on results for the 25 book-to-market and sizesorted portfolios, the failure of the CAPM without option adjustment is evident in the left plot; the intercept term is huge, while the slope coefficient is small and even negative. The improvement in the performance of the CAPM after the option adjustment is significant as seen in the right plot; the intercept term becomes much smaller (dropping from $13.19 \%$ to $1.09 \%$ ), and the slope coefficient of $7.60 \%$ becomes significant. Furthermore, the R-square increases from less than $4 \%$ to almost $60 \%$. 
Panel B examines the Fama-French 48 industry portfolios and underlies similar conclusions. In the case of regression of portfolio excess returns on portfolio betas, the intercept term is huge and significant, while the slope coefficient is small and insignificant. The option adjustment again improves the regression. In the case of regression of optionadjusted portfolio excess returns on option-adjusted portfolio betas, the intercept term becomes close to zero and insignificant (dropping from $8.33 \%$ to $0.11 \%$ ), and the slope coefficient of $6.19 \%$ becomes very significant. Furthermore, the R-square improves from less than $1 \%$ to almost $19 \%$.

\section{3. Cross-sectional regression analysis: subsample}

Table 6 reports the bias-corrected regression results for our subsample, after excluding about $14.6 \%$ of stocks in the full sample whose CAPM betas are likely to be estimated with large errors, by following the procedures described in Mamaysky, Spiegel, and Zhang (2008). Removing these stocks further strengthens support for the CAPM after real option adjustment. For example, in Model 1, a single CAPM beta receives a slope estimate of 65 bps per month (or $7.80 \%$ per year), very close to the historical market risk premium of about $8.00 \%$ in the US. In addition, the intercept term drops to 8 bps per month (or $0.96 \%$ per year) and becomes insignificant $(\mathrm{t}-\mathrm{value}=1.61)$. For the Fama-French three-factor model $($ Model 7), the intercept term becomes even lower at 2 bps per month (or $0.24 \%$ per year) and insignificant. We again find that real option adjustment helps to weaken or even drive out several anomalies that are associated with long-term stock price mean reversion (Ast_gw, Inv, and Lret). 
We thus provide direct evidence suggesting that the failure of the CAPM to explain stock returns is likely attributable to the real options effect. Once these real options are "removed," the CAPM works reasonably well in explaining the risk premium on the primitive projects. The Internet Appendix contains robustness results from additional regressions where we drop one real option proxy at a time. We find our main conclusion to be robust to the exclusion of any of the three proxies.

\section{Conclusion}

We have evaluated the empirical evidence against the standard CAPM from the perspective that it can nevertheless provide a reasonable estimate of a project's cost of capital. To do this, we differentiate the required expected return on potential primitive projects available to a firm from the required expected return on a firm's stocks.

We find that a firm's embedded real option to modify and abandon established projects and undertake new projects may be an important reason behind the poor performance of the CAPM in explaining the cross section of returns on size- and book-to-market-sorted stock portfolios. This lends support to the Berk, Green, and Naik (1999) observation that stock returns need not satisfy the CAPM even when the expected returns on all individual projects do.

We propose a cross sectional regression method for constructing the option-adjusted returns of firms and the corresponding project betas. We provide simulation and empirical evidence supporting the use of the method. When we compute project betas using the cross sectional regression procedure, we find that the CAPM does a reasonable job in explaining option-adjusted stock returns at the individual stock level. 
Levy and Roll (2010) make the interesting observation that small variations in the values of sample parameters can make commonly used market proxies mean variance efficient, and "the CAPM (i.e., ex ante mean/variance efficiency of the market index proxy) is consistent with the empirically observed return parameters and the market proxy portfolio weights." In this paper we provide an alternative explanation for the continued use of the CAPM by finance professionals. Our findings support the view that the CAPM provides a reasonable estimate of a project's cost of capital, provided that any embedded real options associated with the project are evaluated separately for capital budgeting purposes. 


\section{References:}

Abel, A., Dixit, A., Eberly, J., Pindyck, R., 1996. Options, the value of capital, and investment. Quarterly Journal of Economics 111, 753-777.

Adrian, T., Franzoni, F., 2008. Learning about beta: time-varying factor loadings, expected returns, and the conditional CAPM. Unpublished working paper. Federal Reserve Bank of New York.

Anderson, C., Garcia-Feijoo, L., 2006. Empirical evidence on capital investment, growth options, and security returns. Journal of Finance 61, 171-194.

Ang, A., Chen, J., 2007. CAPM Over the long run: 1926-2001. Journal of Empirical Finance 14, 1-40.

Ang, A., Hodrick, R., Xing, Y., Zhang, X., 2006. The cross-section of volatility and expected returns. Journal of Finance 61, 259-299.

Ang, A., Liu, J., 2004. How to discount cashflows with time-varying expected returns. Journal of Finance 59, 2745-2783.

Bali, T., Cakici, N., Tang, Y., 2009. The conditional beta and the cross-section of expected returns. Financial Management 38, 103-137.

Ball, R., Brown, P., 1968. An empirical evaluation of accounting income numbers. Journal of Accounting Research 6, 159-178.

Banz, R. W., 1981. The relationship between return and market value of common stocks. Journal of Financial Economics 9, 3-18.

Basu, S., 1983. The relationship between earnings yield, market value, and return for NYSE common stocks: further evidence. Journal of Financial Economics 12, 129-156.

Bauer, R., Cosemans, M., Frehen, R., Schotman, P., 2009. Efficient estimation of firmspecific betas and its benefits for asset pricing and portfolio choice. Unpublished working paper. University of Amsterdam.

Bekaert, G., Hodrick, R., Zhang, X., 2010. Aggregate idiosyncratic volatility. Unpublished working paper. Columbia University.

Berk, J., 1995. A critique of size-related anomalies. Review of Financial Studies 8, 275286.

Berk, J., Green, R., Naik, V., 1999. Optimal investment, growth options, and security returns. Journal of Finance 54, 1553-1607. 
Benard, V., Thomas, J., 1990. Evidence that stock markets do not fully reflect the implications of current earnings for future earnings. Journal of Accounting and Economics 13, 305-340.

Bernardo, A., Chowdhry, B., Goyal, A., 2007. Growth options, beta, and the cost of capital. Financial Management 36, 5-17.

Black, F., Scholes, H., 1973. The pricing of options and corporate liabilities. Journal of Political Economy 18, 637-659.

Campbell, J., 2003. Consumption-based asset pricing. Chapter 13 in G. Constantinides, M. Harris, and R. Stulz, eds. Handbook of the Economics of Finance, Vol IB. NorthHolland, Amsterdam, pp. 803-887.

Cao, C., Simin, T., Zhao, J., 2008. Can growth options explain the trend in idiosyncratic risk? Review of Financial Studies 21, 2599-2633.

Carlson, M., Fisher, A., Giammarino, R., 2004. Corporate investment and asset price dynamics: implications for the cross-section of returns. Journal of Finance 59, 25772603.

Chan, K., Hameed, A., Lau, S., 2003. What if trading location is different from business location? evidence from the Jardine Group. Journal of Finance 58, 1221-1246.

Chan, K., Jegadeesh, N., Lakonishok, J., 1996. Momentum strategies. Journal of Finance 51, 1681-1713.

Chen, L., Novy-Marx, R., Zhang, L., 2010. An alternative three-factor model. Unpublished working paper. The Ohio State University.

Connor, G., 1984. A unified beta pricing theory. Journal of Economic Theory 34, 13-31.

Cooper, I., 2006. Asset pricing implication of nonconvex adjustment costs and irreversibility of investment. Journal of Finance 61, 139-170.

Cooper, I., Priestley, R., 2010. Real investment, risk and risk dynamics. Unpublished working paper. Norwegian School of Management.

Cooper, M., Gulen, H., Schill, M., 2008. Asset growth and the cross-section of stock returns. Journal of Finance 63, 1609-1652.

DeBondt, W., Thaler, R., 1985. Does the stock market overreact? Journal of Finance 40, 793-805. 
Duffie, D., 2003. Intertemporal asset pricing theory. Chapter 11 in G. Constantinides, M. Harris, and R. Stulz, eds. Handbook of the Economics of Finance, Vol IB. North-Holland, Amsterdam, pp. 639-742.

Dybvig, P., Ingersoll, J., 1982. Mean-variance theory in complete markets. Journal of Business 55, 233-251.

Dybvig, P., Ross, S., 1985. Differential information and performance measurement using a security market line. Journal of Finance 40, 383-399.

Fama, E., French, K., 1992. The cross section of expected stock returns. Journal of Finance 47, 427-465.

Fama, E., French, K., 1993. Common risk factors in stock and bond returns. Journal of Financial Economics 33, 3 -56.

Fama, E., French, K., 1996. The CAPM is wanted, dead or alive. Journal of Finance 51, 1947-1958.

Fama, E., French, K., 1997. Industry cost of capital. Journal of Financial Economics 43, 153-193.

Fama, E., French, K., 1999. The corporate cost of capital and the return on corporate investment. Journal of Finance 54, 1939-1967.

Fama, E., French, K., 2004. The CAPM: theory and evidence. Journal of Economic Perspectives 18, 25-46.

Fama, E., French, K., 2006. The value premium and the CAPM. Journal of Finance 61, 2163-2185.

Fama, E., MacBeth, J., 1973. Risk, return and equilibrium: empirical tests. Journal of Political Economy 81, 607-636.

Ferson, W., 2003. Tests of multifactor pricing models, volatility bounds and portfolio performance. In G. Constantinides, M. Harris and R. Stulz, eds. Handbook of the Economics of Finance. North Holland, Amsterdam, pp. 743-800.

Ferson, W., Locke, D. H., 1998. Estimating the cost of capital through time: an analysis of the sources of error. Management Science 44, 485-500.

Glosten, L., Jagannathan, R., 1994. A contingent claim approach to performance evaluation. Journal of Empirical Finance 1(2), 133-160.

Gomes, J. F., Kogan, L., Zhang, L., 2003. Equilibrium cross-section of returns. Journal of Political Economy 111, 693-732. 
Graham, J. R., Harvey, C., 2001. The theory and practice of corporate finance: evidence from the field. Journal of Financial Economics 60, 187-243.

Gulen, H., Xing, Y., Zhang, L., 2010. Value versus growth: time-varying expected stock returns. Financial Management, forthcoming.

Hansen, L. P., Richard, S., 1987. The role of conditioning information in deducing testable restrictions implied by dynamic asset pricing models. Econometrica 55, 587-613.

Henriksson, R., Merton, R., 1981. On market timing and investment performance II: statistical procedure for evaluating forecasting skills. Journal of Business 54, 513-533.

Hoberg, G., Welch, I., 2007. Aged and recent market betas in securities pricing. Unpublished working paper. Brown University.

Jegadeesh, N., Titman, S., 1993. Returns to buying winners and selling losers: implications for stock market efficiency. Journal of Finance 48, 65-91.

Jagannathan, R., Kim, S., Skoulakis, G., 2010. Revisiting the errors in variables problem in studying the cross section of stock returns. Unpublished working paper. Northwestern University.

Jagannathan, R., Korajczyk, R. A., 1986. Assessing the market timing performance of managed portfolios. Journal of Business 59, 217-235.

Jagannathan, R., Meier, I., 2002. Do we need CAPM for capital budgeting? Financial Management 31, 5-27.

Jagannathan, R., Meier, I. , Tarhan, V., 2011. The cross-section of hurdle rates for capital budgeting: an empirical analysis of survey data. Unpublished working paper.

Northwestern University.

Jagannathan, R., Wang, Z., 1996. The conditional CAPM and the cross-section of expected returns. Journal of Finance 51, 3-53.

Kim, D.,1995. The errors in the variables problem in the cross-section of expected returns. Journal of Finance 50, 1605-1634.

Kumar, P., Srescu, S., Boehme, R., Danielsen, B., 2008. Estimation risk, information, and the conditional CAPM: theory and evidence. Review of Financial Studies 21, 1037-1075.

Lakonishok, J., Shleifer, A., Vishny, R., 1994. Contrarian investment, extrapolation, and risk. Journal of Finance 49, 1541-1578. 
Lettau, M., Ludvigson, S., 2001. Resurrecting the (C)CAPM: A cross-sectional test when risk premia are time-varying. Journal of Political Economy 109, 1238-1287.

Levy, M., Roll, R., 2010. The market portfolio may be mean/variance efficient after all. Review of Financial Studies 23, 2464-2491.

Lewellen, J., Nagel, S., 2006. The conditional CAPM does not explain asset pricing anomalies. Journal of Financial Economics 82, 289-314.

Lintner, J., 1965. The valuation of risky assets and the selection of risky investments in stock portfolios and capital budgets. Review of Economics and Statistics 47, 13-37.

Liu, L. X., Whited, T. M., Zhang, L., 2009. Investment-based expected stock returns. Journal of Political Economy 117, 1105-1139.

Lustig, H., Van Nieuwerburgh, S., 2005. Housing collateral, consumption insurance, and risk premia: an empirical perspective. Journal of Finance 60, 1167-1219.

Mamaysky, H., Spiegel, M., Zhang, H., 2008. Estimating the dynamics of mutual fund alphas and betas. Review of Financial Studies 21, 233-264.

McDonald, R. L., Siegel, D., 1985. Investment and the valuation of firms when there is an option to shut down. International Economic Review 26, 331-349.

Mehra, R., Prescott, E., 2003. The equity premium in retrospect. In G. Constantinides, M. Harris, and R. Stulz, eds. Handbook of the Economics of Finance, Vol IB. North-Holland, Amsterdam, pp. 889-938.

Merton, R., 1981. On market timing and investment performance I: an equilibrium theory of value for market forecasts. Journal of Business 54, 363-406.

Newey, W., West, K., 1987. A simple, positive semi-definite, heteroscedasticity and autocorrelation consistent covariance matrix. Econometrica 55, 703-708.

Pastor, L., Stambaugh, R., 1999. Costs of equity capital and model mispricing. Journal of Finance 54, 67-121.

Pastor, L., Stambaugh, R., 2003. Liquidity risk and expected stock returns. Journal of Political Economy 111, 642-685.

Petkova, P., Zhang, L., 2005. Is value riskier than growth? Journal of Financial Economics 78, 187-202.

Rosenberg, B., Reid, J., Lanstein, R., 1985. Persuasive evidence of market inefficiency. Journal of Portfolio Management 11, 9-17. 
Smith, C., Watts, R., 1992. The investment opportunity set and corporate financing, dividend and compensation policies. Journal of Financial Economics 32, 263-292.

Rubinstein, M., 1976. The valuation of uncertain income streams and the pricing of options. Bell Journal of Economics 7, 407-425.

Ross, S., 1976. The arbitrage theory of capital asset pricing. Journal of Economic Theory 13, 341-360.

Santos, T., Veronesi, P., 2006. Habit formation, the cross section of stock returns and the cash-flow risk puzzle. Unpublished working paper. University of Chicago.

Sharpe, W., 1964. Capital asset prices: a theory of market equilibrium under conditions of risk. Journal of Finance 19, 425-442.

Treynor, J., Mazuy, F., 1966. Can mutual funds outguess the market? Harvard Business Review 44, 131-136.

Wang, K. Q., 2003. Asset pricing with conditioning information: a new test. Journal of Finance 58, 161-196.

Welch, I., 2008. The consensus estimate for the equity premium by academic financial economists in December 2007. Unpublished working paper. Brown University.

Xing, Y., 2008. Interpreting the value effect through the Q-theory: an empirical investigation. Review of Financial Studies 21, 1767-1795.

Zhang, L., 2005. The value premium. Journal of Finance 60, 67-103. 
Figure 1 Option-Adjusted Betas and the CAPM: Simulation Evidence

We generate a large cross-section of firms. Each firm is a portfolio of a primitive asset (project) and a call option on it. The call options expire in one year. We assume a market risk premium $\left(\mu_{M}\right)$ of $8.00 \%$ and a market risk-free rate of $1.00 \%$. We also assume a market volatility of 0.20 (on the log market return). We vary option moneyness ( $k_{i}$ ) from 0.75 to 1.25 in increments of 0.05 . We vary asset idiosyncratic volatility $\left(\mathrm{Ivol}_{i}\right)$ from 0.10 to 0.70 in increments of 0.10 . We vary the primitive project beta ( $\left.\beta_{i}^{p}\right)$ from 0 to 2 in increments of 0.10 . For each firm with a short position in a call option, we also generate two otherwise identical firms, each with a long position in the same option. For each firm, we compute the risk premium $\left(\mu_{i}\right)$ and the CAPM beta $\left(\beta_{i}\right)$ of the stock numerically using Monte Carlo simulations. The option-adjusted beta $\left(\beta_{i}^{O A}\right)$ is the residual of regressing the firm CAPM beta on the option proxies $\left[B M_{i}, k_{i}, \mathrm{IVol}_{i}\right]$ in a cross-sectional regression with no constant. The option-adjusted firm risk premium $\left(\mu_{i}^{O A}\right)$ is the residual of regressing the firm risk premium $\left(\mu_{i}\right)$ on the option proxies in the cross-section with no constant. Finally, we add a measurement error to the CAPM beta, drawn from a normal distribution of zero mean and a variance of 0.01. Panel A plots the firm risk premium against firm CAPM beta. Panel B plots the firm CAPM beta against option-adjusted beta. Panel C plots the option-adjusted risk premium against option-adjusted beta.
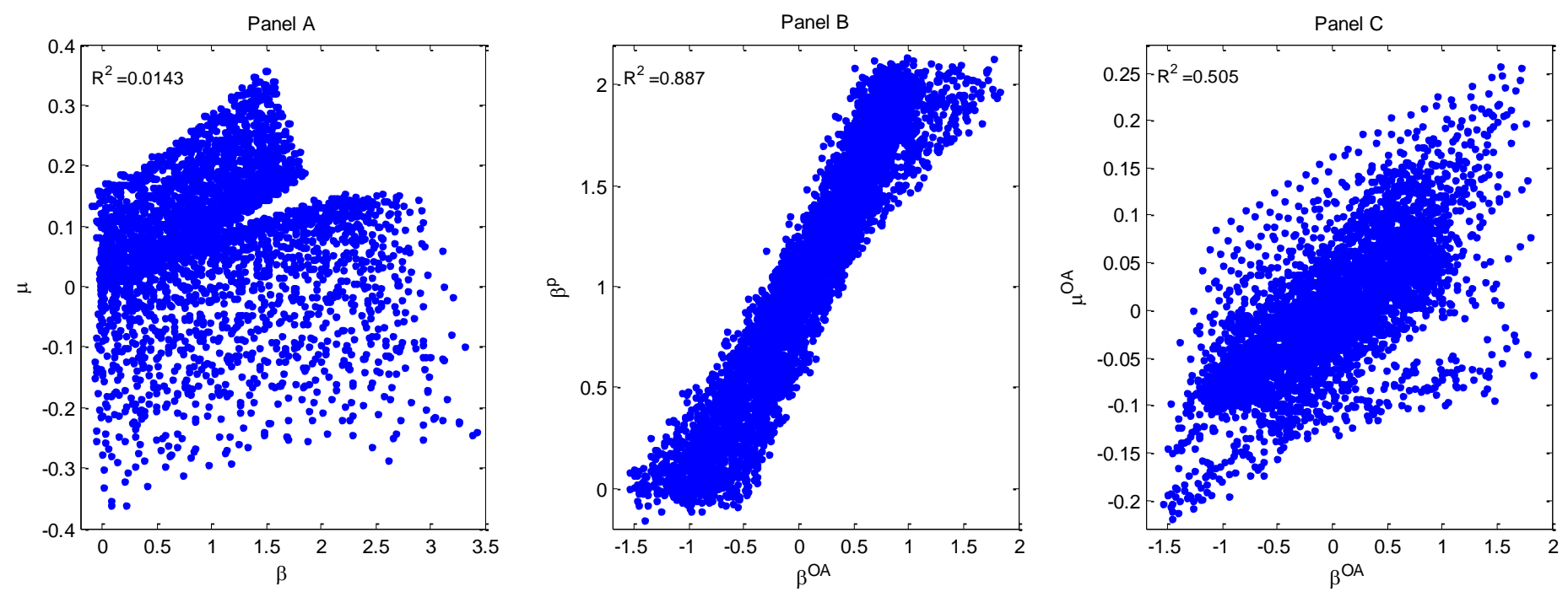


\section{Figure 2 Portfolio Excess Returns and Portfolio Betas}

Lefthand-side graphs plot portfolio average monthly excess returns against portfolio average betas. Righthand-side graphs plot portfolio average option-adjusted excess returns against portfolio average option-adjusted betas. The regression estimates of excess returns on betas are presented below the plots. Panel A examines 25 portfolios sorted on book-to-market and size and Panel B examines 48 industry portfolios constructed using the Fama-French industry classifications. The option adjusted variables are constructed as the residuals from regressing the raw variables with independent variables of BM, Ivol, and ROA.

Panel A: 25 Book-to-market and size- sorted portfolios
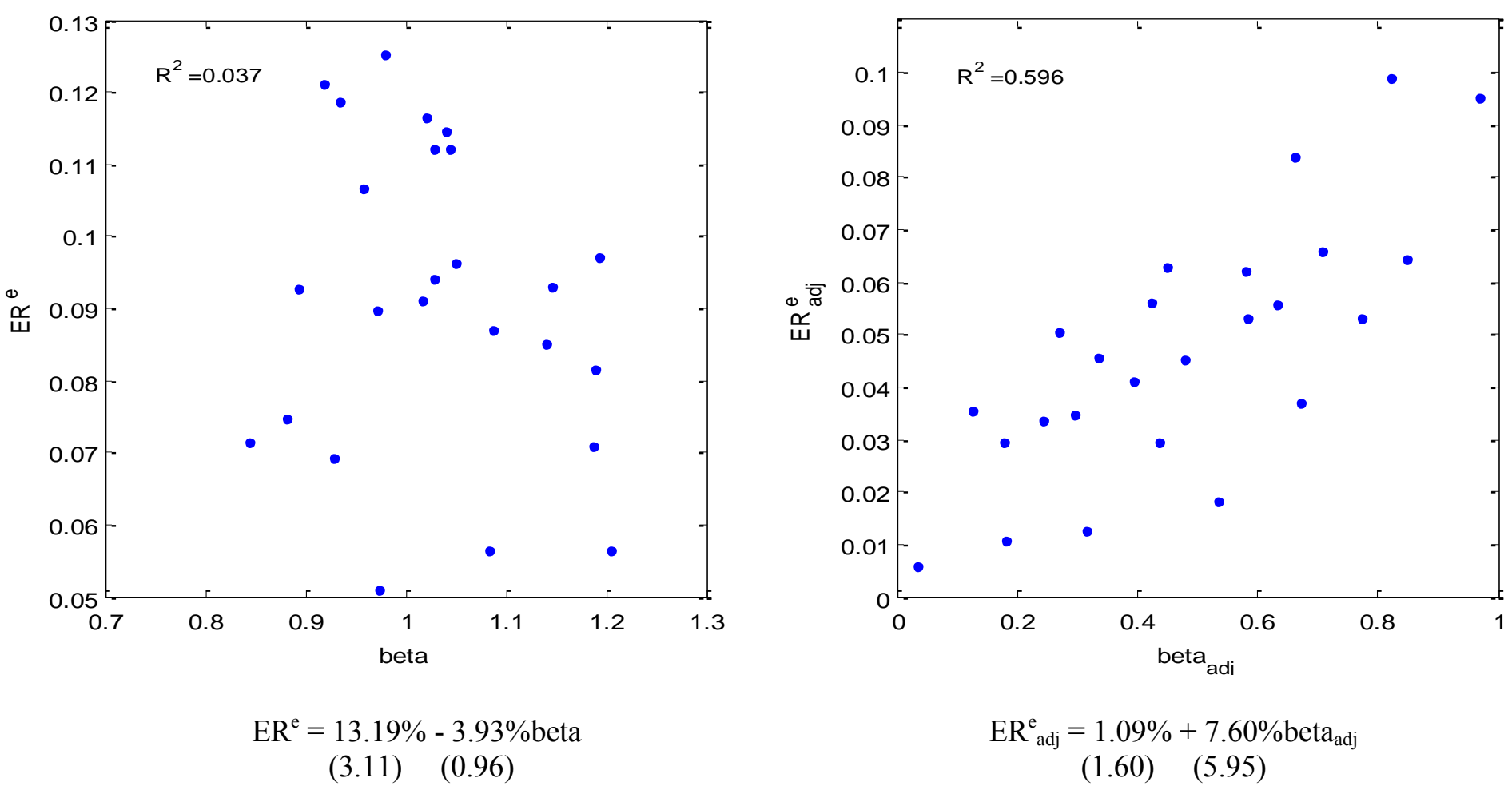
Panel B: 48 Industry portfolios
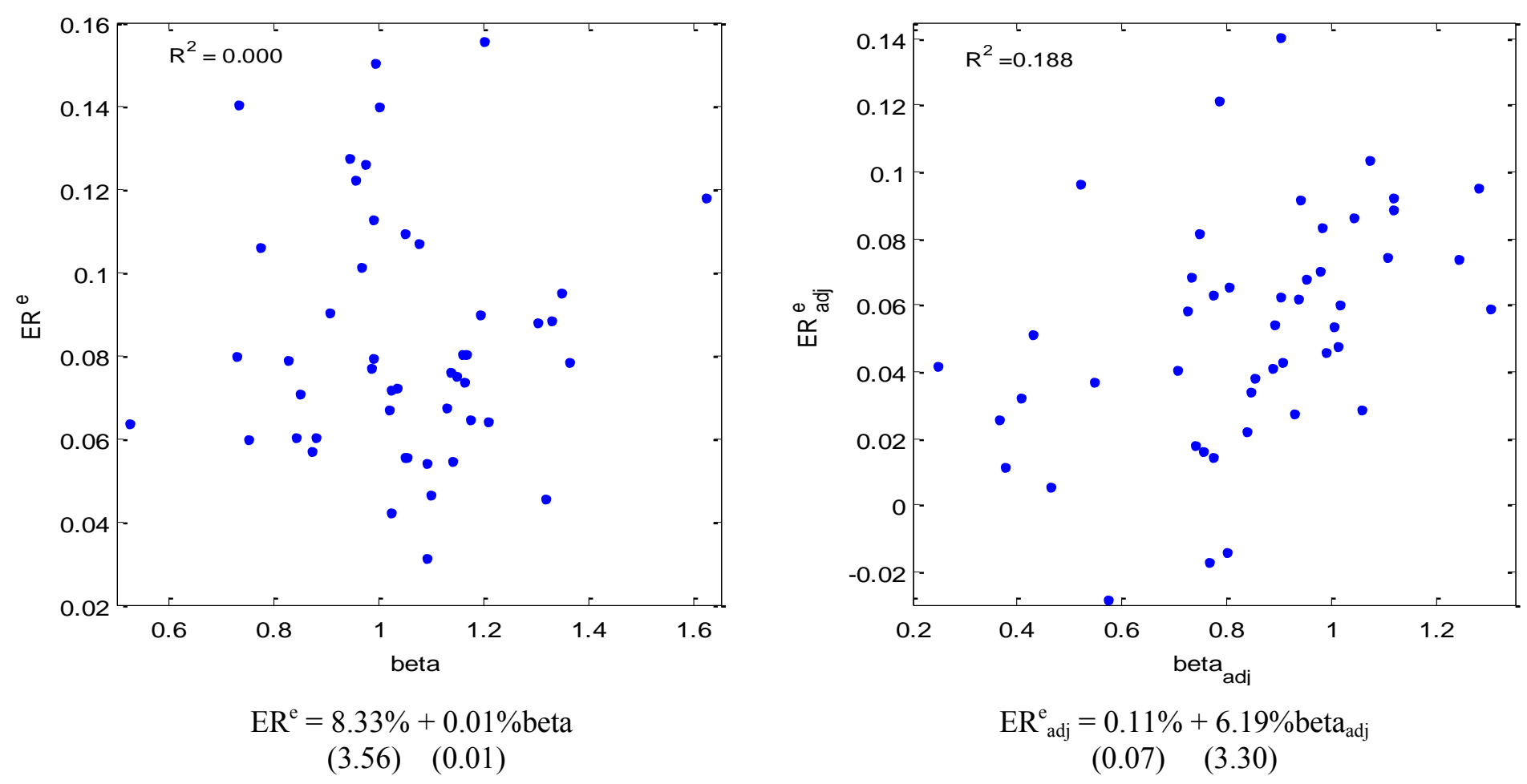
Table 1 Variable Definition

\begin{tabular}{|c|c|}
\hline \begin{tabular}{|l|l} 
Variable \\
\end{tabular} & Definition \\
\hline Beta & $\begin{array}{l}\text { CAPM beta estimated using } 5 \text {-year monthly return data prior to return } \\
\text { measurement in month } t \text {. }\end{array}$ \\
\hline Size & $\begin{array}{l}\text { Market capitalization (in millions) measured on the last trading day of } \\
\text { June. }\end{array}$ \\
\hline $\mathrm{BE}$ & $\begin{array}{l}\text { Book value (in millions). } \\
\text { If the data item of Compustat Data216 is not missing, then BE= } \\
\text { Data216 - Data10 + Data35 + Data79, otherwise BE =Data6 - Data181- } \\
\text { Data10 + Data35 + Data79. }\end{array}$ \\
\hline BM & Ratio of BE to Size. \\
\hline ROA & $\begin{array}{l}\text { Ratio of quarterly earnings scaled by the one-quarter-lagged asset in the } \\
\text { prior quarter. }\end{array}$ \\
\hline Ivol & $\begin{array}{l}\text { Monthly idiosyncratic volatility in month } t-1 \text { computed following the } \\
\text { procedure described in Ang et al. (2006). }\end{array}$ \\
\hline Momt & $\begin{array}{l}\text { Cumulative monthly stock returns of }[\mathrm{t}-13, \mathrm{t}-2] \text { prior to return } \\
\text { measurement in month } t \text {. }\end{array}$ \\
\hline Sue & $\begin{array}{l}\text { Earnings surprise computed using the difference in quarterly earnings } \\
\text { in the }[\mathrm{t}-3, \mathrm{t}-6] \text { window and the corresponding value announced } 4 \\
\text { quarters ago scaled by the standard deviation of the corresponding } \\
\text { earnings change over the previous } 8 \text { quarters prior to return } \\
\text { measurement in month } t \text {. }\end{array}$ \\
\hline Ast_gw & $\begin{array}{l}\text { Growth rate of total asset value in the prior year computed following } \\
\text { the procedure as described in Cooper et al. (2008). }\end{array}$ \\
\hline Inv & $\begin{array}{l}\text { Investment-to-capital ratio as the annual change in sum of gross } \\
\text { property, plant, and equipment and inventories scaled by lagged book } \\
\text { assets as described in Chen et al. (2010). }\end{array}$ \\
\hline Lret & $\begin{array}{l}\text { Cumulative monthly stock returns of }[\mathrm{t}-60, \mathrm{t}-13] \text { prior to return } \\
\text { measurement in month } t \text {. }\end{array}$ \\
\hline $\begin{array}{l}\text { MKT, SMB, } \\
\text { and HML }\end{array}$ & $\begin{array}{l}\text { Fama-French three-factor with MKT as the CRSP value-weighted } \\
\text { return on all stocks, and SMB and HML the size and value factors. }\end{array}$ \\
\hline
\end{tabular}




\section{Table 2 Correlation Matrix}

Pearson correlations of CAPM beta, betas of Fama-French three-factor (Beta_MKT, Beta_sMB, and Beta_HML), other return anomaly variables (Ast_gw, Inv, Lret, Momt, and Sue); and real option variables (BM, Ivol, and ROA) are presented. ***,**, and * denote significance at the $1 \%$, 5\%, and $10 \%$ levels.

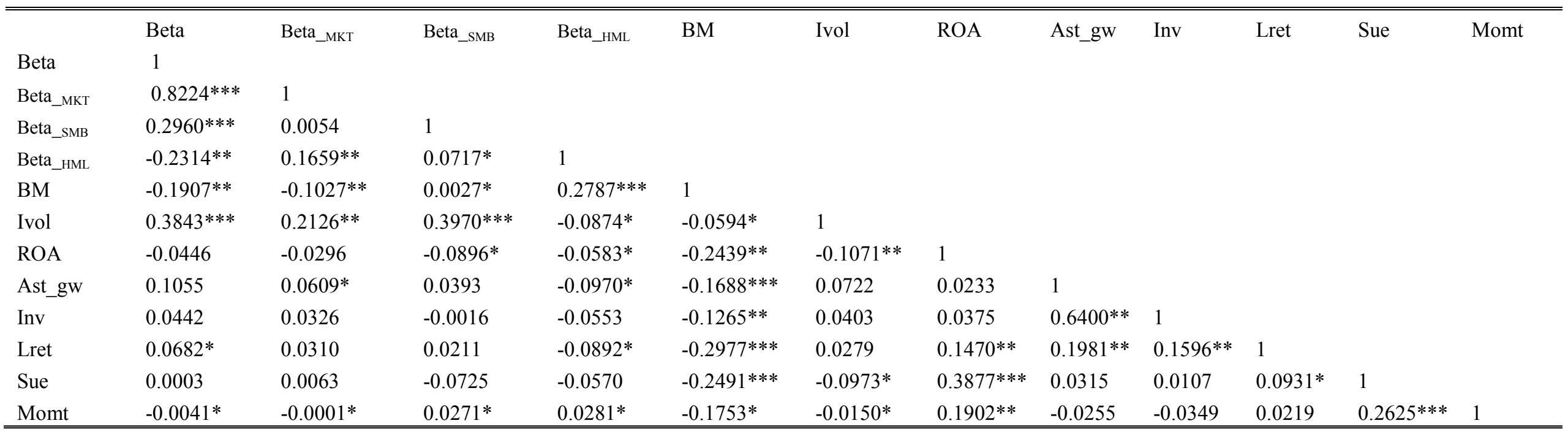


Table 3 Cross-Sectional Regression: Full Sample

The dependent variable is monthly excess returns; independent variables are beta, betas of Fama-French three-factor (Beta_MKт, Beta_smB, and Beta_HML), and the return anomaly variables (Ast_gw, Inv, Lret, Momt, and Sue). The regression coefficients for the sample period of 1970/072008/06 are averaged across time. T-values (in parentheses) are computed using the Fama-MacBeth procedure and the Newey-West (1987) formula with a lag of 36. Log-transformations are applied to Size and BM. There are on average 2,087 stocks each month in our full sample.

\begin{tabular}{|c|c|c|c|c|c|c|c|c|c|c|c|}
\hline Variable & Const. & Beta & Beta_MKT & Beta_SMB & Beta_HML & Ast_gw & Inv & Lret & Sue & Momt & Adj $R^{2}$ \\
\hline Model 1 & $\begin{array}{c}0.0078 \\
(4.21)\end{array}$ & $\begin{array}{l}-0.0001 \\
(-0.09)\end{array}$ & - & - & - & - & - & - & - & - & $2.61 \%$ \\
\hline Model 2 & $\begin{array}{c}0.0084 \\
(4.57)\end{array}$ & $\begin{array}{c}0.0003 \\
(0.21)\end{array}$ & - & - & - & $\begin{array}{l}-0.0082 \\
(-3.79)\end{array}$ & - & - & - & - & $2.83 \%$ \\
\hline Model 3 & $\begin{array}{c}0.0084 \\
(4.42)\end{array}$ & $\begin{array}{c}0.0001 \\
(0.09)\end{array}$ & - & - & - & - & $\begin{array}{c}-0.0098 \\
(-2.57)\end{array}$ & - & - & - & $2.83 \%$ \\
\hline Model 4 & $\begin{array}{c}0.0081 \\
(4.50)\end{array}$ & $\begin{array}{l}-0.0001 \\
(-0.04)\end{array}$ & - & - & - & - & - & $\begin{array}{c}-0.0012 \\
(-2.08)\end{array}$ & - & - & $3.00 \%$ \\
\hline Model 5 & $\begin{array}{c}0.0072 \\
(3.90)\end{array}$ & $\begin{array}{l}-0.0002 \\
(-0.12)\end{array}$ & - & - & - & - & - & - & $\begin{array}{l}0.0015 \\
(6.59)\end{array}$ & - & $3.00 \%$ \\
\hline Model 6 & $\begin{array}{c}0.0066 \\
(3.71)\end{array}$ & $\begin{array}{l}-0.0004 \\
(-0.34)\end{array}$ & - & - & - & - & - & - & - & $\begin{array}{c}0.0075 \\
(5.28)\end{array}$ & $3.71 \%$ \\
\hline Model 7 & $\begin{array}{l}0.0067 \\
(4.19)\end{array}$ & - & $\begin{array}{c}0.0002 \\
(0.21)\end{array}$ & $\begin{array}{c}0.0004 \\
(0.46)\end{array}$ & $\begin{array}{l}0.0022 \\
(2.64)\end{array}$ & - & - & - & - & - & $4.15 \%$ \\
\hline Model 8 & $\begin{array}{c}0.0074 \\
(4.62)\end{array}$ & - & $\begin{array}{c}0.0005 \\
(0.47)\end{array}$ & $\begin{array}{c}0.0004 \\
(0.53)\end{array}$ & $\begin{array}{c}0.0018 \\
(2.29)\end{array}$ & $\begin{array}{c}-0.0068 \\
(-3.78)\end{array}$ & - & - & - & - & $4.31 \%$ \\
\hline Model 9 & $\begin{array}{c}0.0073 \\
(4.39)\end{array}$ & - & $\begin{array}{c}0.0004 \\
(0.39)\end{array}$ & $\begin{array}{c}0.0004 \\
(0.53)\end{array}$ & $\begin{array}{l}0.0019 \\
(2.36)\end{array}$ & - & $\begin{array}{c}-0.0082 \\
(-2.45)\end{array}$ & - & - & - & $4.32 \%$ \\
\hline Model 10 & $\begin{array}{c}0.0071 \\
(4.57)\end{array}$ & - & $\begin{array}{c}0.0004 \\
(0.36)\end{array}$ & $\begin{array}{c}0.0002 \\
(0.25)\end{array}$ & $\begin{array}{c}0.0018 \\
(2.29)\end{array}$ & - & - & $\begin{array}{c}-0.0009 \\
(-2.19)\end{array}$ & - & - & $4.46 \%$ \\
\hline Model 11 & $\begin{array}{l}0.0061 \\
(3.71)\end{array}$ & - & $\begin{array}{c}0.0001 \\
(0.12)\end{array}$ & $\begin{array}{l}0.0006 \\
(0.70)\end{array}$ & $\begin{array}{l}0.0024 \\
(2.94)\end{array}$ & - & - & - & $\begin{array}{l}0.0015 \\
(7.26)\end{array}$ & - & $4.49 \%$ \\
\hline Model 12 & $\begin{array}{c}0.0056 \\
(3.53) \\
\end{array}$ & - & $\begin{array}{l}0.0000 \\
(-0.05) \\
\end{array}$ & $\begin{array}{c}0.0003 \\
(0.45) \\
\end{array}$ & $\begin{array}{c}0.0023 \\
(3.15) \\
\end{array}$ & - & - & - & - & $\begin{array}{r}0.0068 \\
(5.20) \\
\end{array}$ & $5.03 \%$ \\
\hline
\end{tabular}


Table 4 Cross-Sectional Regression after Real Option Adjustment: Full Sample

The dependent variable is the option adjusted monthly excess returns; independent variables are beta, betas of Fama-French three-factor (Beta_mкт, Beta_sмB, and Beta_нмL), and the return anomaly variables (Ast_gw, Inv, Lret, Momt, and Sue). The regression coefficients for the sample period of 1970/07-2008/06 are averaged across time. T-values (in parentheses) are computed using the Fama-MacBeth procedure and the Newey-West (1987) formula with a lag of 36. Log-transformations are applied to Size and BM. The option adjusted variables are constructed as the residuals from regressing the raw variables with independent variables of BM, Ivol, and ROA. There are on average 2,087 stocks each month in our full sample.

\begin{tabular}{|c|c|c|c|c|c|c|c|c|c|c|c|}
\hline & Const. & Beta & Beta_MKT & Beta_SMB & Beta_HML & Ast_gw & Inv & Lret & Sue & Momt & Adj $R^{2}$ \\
\hline Model 1 & $\begin{array}{c}0.0020 \\
(3.14)\end{array}$ & $\begin{array}{c}0.0042 \\
(3.35)\end{array}$ & - & - & - & - & - & - & - & - & $3.90 \%$ \\
\hline Model 2 & $\begin{array}{c}0.0021 \\
(3.38)\end{array}$ & $\begin{array}{c}0.0046 \\
(3.98)\end{array}$ & - & - & - & $\begin{array}{c}-0.0043 \\
(-2.34)\end{array}$ & - & - & - & - & $4.08 \%$ \\
\hline Model 3 & $\begin{array}{c}0.0020 \\
(3.25)\end{array}$ & $\begin{array}{c}0.0045 \\
(3.74)\end{array}$ & - & - & - & - & $\begin{array}{c}-0.0048 \\
(-1.49)\end{array}$ & - & - & - & $4.09 \%$ \\
\hline Model 4 & $\begin{array}{c}0.0019 \\
(3.60)\end{array}$ & $\begin{array}{c}0.0044 \\
(3.67)\end{array}$ & - & - & - & - & - & $\begin{array}{r}-0.0004 \\
(-0.94)\end{array}$ & - & - & $4.16 \%$ \\
\hline Model 5 & $\begin{array}{c}0.0016 \\
(2.78)\end{array}$ & $\begin{array}{l}0.0035 \\
(2.79)\end{array}$ & - & - & - & - & - & - & $\begin{array}{c}0.0016 \\
(9.75)\end{array}$ & - & $4.10 \%$ \\
\hline Model 6 & $\begin{array}{c}0.0014 \\
(2.61)\end{array}$ & $\begin{array}{c}0.0031 \\
(2.66)\end{array}$ & - & - & - & - & - & - & - & $\begin{array}{c}0.0080 \\
(6.52)\end{array}$ & $4.78 \%$ \\
\hline Model 7 & $\begin{array}{c}0.0016 \\
(3.06)\end{array}$ & - & $\begin{array}{c}0.0041 \\
(3.58)\end{array}$ & $\begin{array}{c}0.0017 \\
(1.98)\end{array}$ & $\begin{array}{c}0.0009 \\
(1.43)\end{array}$ & - & - & - & - & - & $4.97 \%$ \\
\hline Model 8 & $\begin{array}{c}0.0017 \\
(3.33)\end{array}$ & - & $\begin{array}{l}0.0045 \\
(4.24)\end{array}$ & $\begin{array}{c}0.0018 \\
(2.17)\end{array}$ & $\begin{array}{c}0.0007 \\
(1.13)\end{array}$ & $\begin{array}{c}-0.0041 \\
(-2.32)\end{array}$ & - & - & - & - & $5.12 \%$ \\
\hline Model 9 & $\begin{array}{c}0.0017 \\
(3.18)\end{array}$ & - & $\begin{array}{c}0.0044 \\
(4.00)\end{array}$ & $\begin{array}{c}0.0018 \\
(2.15)\end{array}$ & $\begin{array}{c}0.0007 \\
(1.15)\end{array}$ & - & $\begin{array}{r}-0.0047 \\
(-1.65)\end{array}$ & - & - & - & $5.12 \%$ \\
\hline Model 10 & $\begin{array}{c}0.0016 \\
(3.53)\end{array}$ & - & $\begin{array}{c}0.0044 \\
(4.05)\end{array}$ & $\begin{array}{l}0.0017 \\
(1.92)\end{array}$ & $\begin{array}{l}0.0007 \\
(1.21)\end{array}$ & - & - & $\begin{array}{c}-0.0005 \\
(-1.21)\end{array}$ & - & - & $5.19 \%$ \\
\hline Model 11 & $\begin{array}{l}0.0013 \\
(2.66)\end{array}$ & - & $\begin{array}{c}0.0034 \\
(2.96)\end{array}$ & $\begin{array}{c}0.0016 \\
(1.86)\end{array}$ & $\begin{array}{c}0.0009 \\
(1.51)\end{array}$ & - & - & - & $\begin{array}{l}0.0016 \\
(9.82)\end{array}$ & - & $5.15 \%$ \\
\hline Model 12 & $\begin{array}{c}0.0011 \\
(2.48)\end{array}$ & - & $\begin{array}{c}0.0031 \\
(2.85)\end{array}$ & $\begin{array}{c}0.0014 \\
(1.71)\end{array}$ & $\begin{array}{c}0.0007 \\
(1.40)\end{array}$ & - & - & - & - & $\begin{array}{c}0.0073 \\
(6.21)\end{array}$ & $5.67 \%$ \\
\hline
\end{tabular}


Table 5 Bias-Corrected Cross-Sectional Regression with Real Option Adjustment: Full Sample

The dependent variable is option adjusted monthly excess returns; independent variables are beta, betas of Fama-French three-factor (Beta_мкт, Beta_sмB, and Beta_нмL), and the return anomaly variables. The regression coefficients for the sample period of 1970/07-2008/06 are first corrected using procedures described in the Internet Appendix and averaged across time. T-values (in parentheses) are computed using the FamaMacBeth procedure and the Newey-West (1987) formula with a lag of 36. Log-transformations are applied to Size and BM. The option adjusted variables are constructed as the residuals from regressing the raw variables with independent variables of BM, Ivol, and ROA. There are on average 2,087 stocks each month in our full sample.

\begin{tabular}{|c|c|c|c|c|c|c|c|c|c|c|c|}
\hline & Const. & Beta & Beta_MKT & Beta_sMB & Beta_HML & Ast_gw & Inv & Lret & Sue & Momt & $\operatorname{Adj} R^{2}$ \\
\hline Model 1 & $\begin{array}{l}0.0014 \\
(2.45)\end{array}$ & $\begin{array}{l}0.0053 \\
(3.42)\end{array}$ & - & - & - & - & - & - & - & - & $1.80 \%$ \\
\hline Model 2 & $\begin{array}{l}0.0014 \\
(2.56)\end{array}$ & $\begin{array}{l}0.0061 \\
(4.05)\end{array}$ & - & - & - & $\begin{array}{c}-0.0057 \\
(-3.26)\end{array}$ & - & - & - & - & $1.99 \%$ \\
\hline Model 3 & $\begin{array}{l}0.0014 \\
(2.54)\end{array}$ & $\begin{array}{l}0.0059 \\
(3.80)\end{array}$ & - & - & - & - & $\begin{array}{c}-0.0065 \\
(-1.94)\end{array}$ & - & - & - & $1.96 \%$ \\
\hline Model 4 & $\begin{array}{l}0.0013 \\
(2.72)\end{array}$ & $\begin{array}{c}0.0058 \\
(3.73)\end{array}$ & - & - & - & - & - & $\begin{array}{c}-0.0006 \\
(-1.38)\end{array}$ & - & - & $1.96 \%$ \\
\hline Model 5 & $\begin{array}{l}0.0012 \\
(2.18)\end{array}$ & $\begin{array}{l}0.0045 \\
(2.82)\end{array}$ & - & - & - & - & - & - & $\begin{array}{c}0.0016 \\
(8.49)\end{array}$ & - & $1.94 \%$ \\
\hline Model 6 & $\begin{array}{c}0.0009 \\
(1.98)\end{array}$ & $\begin{array}{c}0.0039 \\
(2.70)\end{array}$ & - & - & - & - & - & - & - & $\begin{array}{c}0.0083 \\
(7.13)\end{array}$ & $2.77 \%$ \\
\hline Model 7 & $\begin{array}{c}0.0006 \\
(1.96)\end{array}$ & - & $\begin{array}{l}0.0054 \\
(3.53)\end{array}$ & $\begin{array}{c}0.0024 \\
(1.47)\end{array}$ & $\begin{array}{c}0.0030 \\
(1.82)\end{array}$ & - & - & - & - & - & $1.18 \%$ \\
\hline Model 8 & $\begin{array}{l}0.0007 \\
(2.16)\end{array}$ & - & $\begin{array}{l}0.0059 \\
(4.06)\end{array}$ & $\begin{array}{c}0.0025 \\
(1.57)\end{array}$ & $\begin{array}{c}0.0026 \\
(1.66)\end{array}$ & $\begin{array}{c}-0.0045 \\
(-2.94)\end{array}$ & - & - & - & - & $1.23 \%$ \\
\hline Model 9 & $\begin{array}{l}0.0007 \\
(2.12)\end{array}$ & - & $\begin{array}{l}0.0058 \\
(3.87)\end{array}$ & $\begin{array}{l}0.0026 \\
(1.60)\end{array}$ & $\begin{array}{l}0.0026 \\
(1.66)\end{array}$ & - & $\begin{array}{c}-0.0056 \\
(-2.18)\end{array}$ & - & - & - & $1.30 \%$ \\
\hline Model 10 & $\begin{array}{l}0.0007 \\
(2.20)\end{array}$ & - & $\begin{array}{c}0.0059 \\
(3.96)\end{array}$ & $\begin{array}{c}0.0024 \\
(1.48)\end{array}$ & $\begin{array}{c}0.0028 \\
(1.71)\end{array}$ & - & - & $\begin{array}{c}-0.0007 \\
(-2.08)\end{array}$ & - & - & $1.28 \%$ \\
\hline Model 11 & $\begin{array}{c}0.0005 \\
(1.56)\end{array}$ & - & $\begin{array}{c}0.0046 \\
(2.96)\end{array}$ & $\begin{array}{c}0.0023 \\
(1.45)\end{array}$ & $\begin{array}{c}0.0028 \\
(1.80)\end{array}$ & - & - & - & $\begin{array}{l}0.0013 \\
(8.34)\end{array}$ & - & $1.34 \%$ \\
\hline Model 12 & $\begin{array}{c}0.0004 \\
(1.48) \\
\end{array}$ & - & $\begin{array}{l}0.0039 \\
(2.54) \\
\end{array}$ & $\begin{array}{c}0.0029 \\
(1.66) \\
\end{array}$ & $\begin{array}{c}0.0035 \\
(1.67) \\
\end{array}$ & - & - & - & - & $\begin{array}{c}0.0049 \\
(2.52) \\
\end{array}$ & $1.71 \%$ \\
\hline
\end{tabular}


Table 6 Bias-Corrected Cross-Sectional Regression with Option Adjustment: Subsample

Cross-sectional regression analysis is conducted on the subsample of stocks after excluding stocks whose betas are likely estimated with large errors. The dependent variable is the optioned-adjusted monthly excess returns; independent variables are beta, betas of Fama-French three-factor (Beta_MKT, Beta_smB, and Beta_HML) and the return anomaly variables. The regression coefficients for the sample period of 1970/07-2008/06 are first corrected using procedures described in the Internet Appendix and averaged across time. T-values (in parentheses) are computed using the Fama-MacBeth procedure and the Newey-West (1987) formula with a lag of 36. Log-transformations are applied to Size and BM. The option adjusted variables are constructed as the residuals from regressing the raw variables with independent variables of BM, Ivol, and ROA. There are on average 1,783 stocks each month in our subsample.

\begin{tabular}{|c|c|c|c|c|c|c|c|c|c|c|c|}
\hline & Const. & Beta & Beta $\_$MKT & Beta_SMB & Beta_HML & Ast_gw & Inv & Lret & Sue & Momt & Adj $R^{2}$ \\
\hline Model 1 & $\begin{array}{c}0.0008 \\
(1.61)\end{array}$ & $\begin{array}{c}0.0065 \\
(3.75)\end{array}$ & - & - & - & - & - & - & - & - & $1.64 \%$ \\
\hline Model 2 & $\begin{array}{c}0.0008 \\
(1.57)\end{array}$ & $\begin{array}{c}0.0074 \\
(4.31)\end{array}$ & - & - & - & $\begin{array}{c}-0.0054 \\
(-3.11)\end{array}$ & - & - & - & - & $1.85 \%$ \\
\hline Model 3 & $\begin{array}{c}0.0008 \\
(1.61)\end{array}$ & $\begin{array}{c}0.0072 \\
(4.05)\end{array}$ & - & - & - & - & $\begin{array}{c}-0.0065 \\
(-1.76)\end{array}$ & - & - & - & $1.80 \%$ \\
\hline Model 4 & $\begin{array}{c}0.0007 \\
(1.62)\end{array}$ & $\begin{array}{c}0.0071 \\
(4.05)\end{array}$ & - & - & - & - & - & $\begin{array}{c}-0.0005 \\
(-1.38)\end{array}$ & - & - & $1.80 \%$ \\
\hline Model 5 & $\begin{array}{c}0.0007 \\
(1.46)\end{array}$ & $\begin{array}{c}0.0056 \\
(3.10)\end{array}$ & - & - & - & - & - & - & $\begin{array}{c}0.0015 \\
(7.97)\end{array}$ & - & $1.87 \%$ \\
\hline Model 6 & $\begin{array}{c}0.0005 \\
(1.28)\end{array}$ & $\begin{array}{l}0.0047 \\
(2.98)\end{array}$ & - & - & - & - & - & - & - & $\begin{array}{l}0.0087 \\
(7.75)\end{array}$ & $2.67 \%$ \\
\hline Model 7 & $\begin{array}{c}0.0002 \\
(0.60)\end{array}$ & - & $\begin{array}{c}0.0063 \\
(3.42)\end{array}$ & $\begin{array}{c}0.0024 \\
(1.36)\end{array}$ & $\begin{array}{c}0.0024 \\
(1.24)\end{array}$ & - & - & - & - & - & $0.83 \%$ \\
\hline Model 8 & $\begin{array}{c}0.0002 \\
(0.63)\end{array}$ & - & $\begin{array}{c}0.0069 \\
(3.73)\end{array}$ & $\begin{array}{c}0.0025 \\
(1.45)\end{array}$ & $\begin{array}{c}0.0022 \\
(1.12)\end{array}$ & $\begin{array}{c}-0.0040 \\
(-2.77)\end{array}$ & - & - & - & - & $0.99 \%$ \\
\hline Model 9 & $\begin{array}{c}0.0002 \\
(0.72)\end{array}$ & - & $\begin{array}{c}0.0068 \\
(3.58)\end{array}$ & $\begin{array}{c}0.0026 \\
(1.49)\end{array}$ & $\begin{array}{c}0.0021 \\
(1.07)\end{array}$ & - & $\begin{array}{c}-0.0053 \\
(-1.78)\end{array}$ & - & - & - & $0.89 \%$ \\
\hline Model 10 & $\begin{array}{c}0.0002 \\
(0.63)\end{array}$ & - & $\begin{array}{c}0.0070 \\
(3.80)\end{array}$ & $\begin{array}{c}0.0024 \\
(1.38)\end{array}$ & $\begin{array}{c}0.0021 \\
(1.08)\end{array}$ & - & - & $\begin{array}{c}-0.0006 \\
(-2.34)\end{array}$ & - & - & $0.97 \%$ \\
\hline Model 11 & $\begin{array}{c}0.0001 \\
(0.33)\end{array}$ & - & $\begin{array}{c}0.0054 \\
(2.90)\end{array}$ & $\begin{array}{c}0.0024 \\
(1.36)\end{array}$ & $\begin{array}{c}0.0023 \\
(1.20)\end{array}$ & - & - & - & $\begin{array}{c}0.0012 \\
(7.30)\end{array}$ & - & $1.01 \%$ \\
\hline Model 12 & $\begin{array}{c}0.0001 \\
(0.29)\end{array}$ & - & $\begin{array}{c}0.0060 \\
(3.32)\end{array}$ & $\begin{array}{c}0.0006 \\
(0.27)\end{array}$ & $\begin{array}{r}-0.0017 \\
(-0.42)\end{array}$ & - & - & - & - & $\begin{array}{c}0.0074 \\
(4.34)\end{array}$ & $1.36 \%$ \\
\hline
\end{tabular}




\section{Appendices with Supplementary Materials for CAPM for Estimating Cost of Equity Capital: Interpreting the Empirical Evidence}

This document contains supplementary material to the paper titled "CAPM for estimating cost of equity capital: Interpreting the empirical evidence.” Appendix A describes the procedures we adapt from Jagannathan, Kim, and Skoulakis (2010) to correct the biased cross-sectional regression estimates for the errors-in-variables problem. Appendix B presents results from additional cross-sectional regressions where we drop one real option proxy at a time.

\section{Appendix A Bias correction in three-stage cross-sectional regression}

The cross-sectional regressions in Section 4.2 and Tables 5 and 6 are ran in three stages. In the first stage, we estimate betas using a rolling-window time-series regression with a window length equal to 60 months. In the second stage, we conduct real options adjustment by projecting returns and betas on option-related stock characteristics in the cross-section and compute the residuals. In the third stage, we regress option-adjusted returns on option-adjusted betas and other return anomaly variables in the cross-section following the Fama-MacBeth (1973) procedure.

Since betas are estimated with errors in the first stage, we will have an errors-in-variables problem in the final cross-sectional regression, resulting in biased risk premium estimates as observed by Kim (1995). The procedures described here are adapted from procedures in Jagannathan, Kim, and Skoulakis (2010).

In the first stage, for each stock, at time $\mathrm{T}$, we estimate the beta(s) using a rolling window time-series regression from $\mathrm{T}-\mathrm{K}$ to $\mathrm{T}-1$ as follows:

$$
R_{i, t}=\alpha_{i}+\beta_{i} x_{t}+\varepsilon_{i, t}
$$

where $\beta_{\mathrm{i}}$ and $\mathrm{x}_{\mathrm{t}}$ are $\mathrm{M}$ by 1 vectors. We ignore the time $\mathrm{T}$ subscript throughout the appendix. To further simplify notation, we define the following:

$$
\begin{gathered}
R_{i}=\left(\begin{array}{c}
R_{i, T-1} \\
\cdots \\
R_{i, T-K}
\end{array}\right) \\
X=\left(\begin{array}{ccc}
x_{T-1}^{1} & \cdots & x_{T-1}^{M} \\
\cdots & \cdots & \cdots \\
x_{T-K}^{1} & \cdots & x_{T-K}^{M}
\end{array}\right)
\end{gathered}
$$




$$
\varepsilon_{i}=\left(\begin{array}{c}
\varepsilon_{i, T-1} \\
\cdots \\
\varepsilon_{i, T-K}
\end{array}\right)
$$

(A-1) can be rewritten in matrix form as follows:

$$
R_{i}=\left(\begin{array}{ll}
1 & X
\end{array}\right)\left(\begin{array}{c}
\alpha_{i} \\
\beta_{i}
\end{array}\right)+\varepsilon_{i}
$$

After de-meaning $\mathrm{R}_{\mathrm{i}}$ and $\mathrm{X}$ for simple notation, we get:

$$
\beta_{i}^{O L S}=\left(X^{\prime} X\right)^{-1} X^{\prime} R_{i}=\beta_{i}+\left(X^{\prime} X\right)^{-1} X^{\prime} \varepsilon_{i}
$$

In the second stage, at each time $\mathrm{T}$, we run cross-sectional regressions without constants to compute option-adjusted returns and residual betas:

$$
\begin{gathered}
R=Z A+\tilde{R}, \\
\beta^{O L S}=Z B+\tilde{\beta}^{O L S},
\end{gathered}
$$

where $\mathrm{Z}$ is an $\mathrm{N}$ by $\mathrm{P}$ matrix of real option proxies (assuming to be measured without errors). Estimates of loadings are:

$$
\begin{gathered}
\hat{A}=\left(Z^{\prime} Z\right)^{-1} Z^{\prime} R, \\
\hat{B}=\left(Z^{\prime} Z\right)^{-1} Z^{\prime} \beta^{O L S}
\end{gathered}
$$

As a result:

$$
\begin{gathered}
\tilde{R}=K R, \\
\tilde{\beta}^{O L S}=K \beta^{O L S}, \\
K=I-Z\left(Z^{\prime} Z\right)^{-1} Z^{\prime} .
\end{gathered}
$$

$\mathrm{K}$ is $\mathrm{N}$ by $\mathrm{N}$ symmetric and idempotent. It rotates the original returns and betas to remove the option effect from the cross-section. The CAPM holds better with the option-adjusted returns and betas.

In the third stage, we run Fama-MacBeth cross-sectional regressions. At time $\mathrm{T}$, we have the cross-sectional regression:

$$
K R_{i, t}=\gamma_{0}+\gamma_{1} K \beta_{i}+\gamma_{2} V_{i, t}+\varepsilon_{i, t},
$$

where $\gamma_{0}=\gamma_{2}=0$ under the null. $\mathrm{V}$ captures additional characteristics measured without error. $V_{i, T}$ and $\gamma_{2}$ are L by 1 vectors. To simplify notation, we define:

$$
K R_{T}=K\left(\begin{array}{c}
\gamma_{1, T} \\
\cdots \\
\gamma_{N, T}
\end{array}\right), K \beta=K\left(\begin{array}{c}
\beta_{1}^{\prime} \\
\cdots \\
\beta^{\prime}{ }_{N}
\end{array}\right), K B=K\left(\begin{array}{c}
\beta_{1}^{O L S^{\prime}} \\
\ldots \\
\beta_{N}^{O L S^{\prime}}
\end{array}\right)
$$




$$
\varepsilon_{T}=\left(\begin{array}{c}
\varepsilon_{1, T} \\
\cdots \\
\varepsilon_{N, T}
\end{array}\right), V=\left(\begin{array}{c}
V_{1, T}^{\prime} \\
\cdots \\
V_{N, T}^{\prime}
\end{array}\right), \varepsilon=\left(\begin{array}{c}
\varepsilon_{1} \\
\cdots \\
\varepsilon_{N}
\end{array}\right)
$$

(A-5) can be rewritten as:

$$
\begin{gathered}
K R_{T}=\gamma_{0}+K \beta \gamma_{1}+V \gamma_{2}+\varepsilon_{T} \\
=\gamma_{0}+K B \gamma_{1}+V \gamma_{2}-K \varepsilon^{\prime} X\left(X^{\prime} X\right)^{-1} \gamma_{1}+\varepsilon_{T},
\end{gathered}
$$

or:

$\left[\begin{array}{lll}1 & K B & V\end{array}\right]^{\prime} K R_{T}=\left[\begin{array}{llll}1 & K B & V\end{array}\right]^{\prime}\left[\begin{array}{lll}1 & K B & V\end{array}\right]\left[\begin{array}{l}\gamma_{0} \\ \gamma_{1} \\ \gamma_{2}\end{array}\right]+\left[\begin{array}{lll}1 & K B & V\end{array}\right]^{\prime}\left[\begin{array}{l}-K \varepsilon^{\prime} X\left(X^{\prime} X\right)^{-1} \gamma_{1}+\varepsilon_{T}\end{array}\right]$ Multiplying both sides by $\left[\begin{array}{llll}1 & K B & V\end{array}\right]^{\prime}\left[\begin{array}{lll}1 & K B & V\end{array}\right]^{-1}$, we have:

$$
\left.\left[\begin{array}{l}
\gamma_{0} \\
\gamma_{1} \\
\gamma_{2}
\end{array}\right]^{O L S}=\left[\begin{array}{l}
\gamma_{0} \\
\gamma_{1} \\
\gamma_{2}
\end{array}\right]+\left[\begin{array}{lll}
1 & K B & V
\end{array}\right]^{\prime}\left[\begin{array}{lll}
1 & K B & V
\end{array}\right]\right]^{-1}\left[\begin{array}{c}
1 \\
K B \\
V
\end{array}\right]\left[-K \varepsilon^{\prime} X\left(X^{\prime} X\right)^{-1} \gamma_{1}+\varepsilon_{T}\right]
$$

We assume $\mu_{y}=\lim _{N \rightarrow \infty} \sum_{i=1}^{N} \frac{y_{i}}{N}$, a cross-sectional mean of a vector of random variables, and

$$
\mu_{x y}=\lim _{N \rightarrow \infty} \sum_{i=1}^{N} \frac{\left(x_{i}-\mu_{x}\right)\left(y_{i}-\mu_{y}\right)}{N}
$$

a cross-sectional covariance of vectors of random variables. We also assume all the second moments to be finite and the usual orthogonality condition holds.

We focus on the second term of the RHS in Equation (A-6). As $N \rightarrow \infty$ :

$$
\begin{array}{r}
{\left[\begin{array}{ccc}
1^{\prime} 1 & 1^{\prime} K B & 1^{\prime} V^{\prime} \\
B^{\prime} K^{\prime} 1 & B^{\prime} K^{\prime} K B & B^{\prime} K^{\prime} V \\
V^{\prime} 1 & V^{\prime} K B & V^{\prime} V
\end{array}\right]^{-1}\left[\begin{array}{c}
1^{\prime} \\
B^{\prime} K^{\prime} \\
V^{\prime}
\end{array}\right]\left[\left[-K \varepsilon^{\prime} X\left(X^{\prime} X\right)^{-1} \gamma_{1}+\varepsilon_{T}\right]\right]} \\
=\left[\begin{array}{ccc}
1^{\prime} 1 & \frac{1^{\prime} K B}{N} & \frac{1^{\prime} V^{\prime}}{N} \\
\frac{B^{\prime} K^{\prime} 1}{N} & \frac{B^{\prime} K^{\prime} K B}{N} & \frac{B^{\prime} K^{\prime} V}{N} \\
\frac{N}{N} 1 & \frac{V^{\prime} K B}{N} & \frac{V^{\prime} V}{N}
\end{array}\right]\left[\begin{array}{c}
\frac{-K \varepsilon^{\prime} X\left(X^{\prime} X\right)^{-1}}{N} \gamma_{1}+\frac{1^{\prime} \varepsilon_{T}}{N} \\
\frac{-B^{\prime} K^{\prime} K \varepsilon^{\prime} X\left(X^{\prime} X\right)^{-1}}{N} \gamma_{1}+\frac{B^{\prime} K^{\prime} \varepsilon_{T}}{N} \\
\frac{-V K^{\prime} \varepsilon^{\prime} X\left(X^{\prime} X\right)^{-1}}{N} \gamma_{1}+\frac{V^{\prime} \varepsilon_{T}}{N}
\end{array}\right] \rightarrow-Q\left[\begin{array}{l}
\gamma_{0} \\
\gamma_{1} \\
\gamma_{2}
\end{array}\right]
\end{array}
$$

Where:

$$
Q=\left[\begin{array}{ccc}
1 & E[K B] & E[V] \\
E\left[B^{\prime} K^{\prime}\right] & E\left[B^{\prime} K^{\prime} K B\right] & E\left[B^{\prime} K^{\prime} V\right] \\
E\left[V^{\prime}\right] & E\left[V^{\prime} K B\right] & E\left[V^{\prime} V\right]
\end{array}\right]^{-1}\left[\begin{array}{ccc}
0 & 0 & 0 \\
0 & S & 0 \\
0 & 0 & 0
\end{array}\right]
$$

In the expression above, $\mathrm{E}[\cdot]$ denotes the cross-sectional means, estimated using sample 
moments. $S=\left(X^{\prime} X\right)^{-1} X^{\prime} \Sigma_{K} X\left(X^{\prime} X\right)^{-1}$, where $\sum_{K}=E\left[\varepsilon K^{\prime} K \varepsilon^{\prime}\right]$.

\section{Appendix B Additional cross-sectional regression results}

We report results from additional cross-sectional regressions after real option adjustment (with bias-correction) where we drop one real option proxy at a time. Table B1 (excluding Ivol), B2 (excluding BM), and B3 (excluding ROA) present results on our full sample. Table B4 (excluding Ivol), B5 (excluding BM), and B6 (excluding ROA) present the corresponding results on the subsample, where we remove about $14 \%$ of the stocks whose betas are most likely to be measured with noise.

Overall, our main conclusions are robust to the exclusion of any of the three real option proxies. In all six tables, the CAPM betas are associated with positive and significant coefficients. When comparing Table B1-B6 in the Appendix to Table 5-6 in the paper, we find all three real option proxies to be useful. The standard CAPM (Model 1) always perform better with smaller intercept term and higher risk premium estimate when all three real option proxies are included.

In the paper, we have used BM as a real option proxy. Berk (1995) argues that BM in general will be a good proxy for expected return as well, even in an economy where the CAPM holds, and could be a better expected return proxy when the beta is estimated with error. In such an economy, the book-to-market ratio will drive out historical betas in explaining the cross-section of stock returns. Hence, our finding that the CAPM beta helps to explain the cross-section of returns after controlling for BM only strengthens our argument in favor of the CAPM for project cost of capital calculation. Nevertheless, we also consider excluding BM as a real option proxy and report the bias-corrected regression results in Table B2 and B5. The key finding here is that the CAPM beta remains highly significant and the intercept term becomes insignificant in the subsample. The anomaly variables become slightly more significant after the exclusion of BM in the real option adjustment, which is not too surprising as BM is considered as an important real option proxy. 
Table B1: Bias-Corrected Cross-Sectional Regression with Real Option Adjustment: Full Sample

The dependent variable is option adjusted monthly excess returns; independent variables are beta, betas of Fama-French three-factor (Beta_mкт, Beta_sмв, and Beta_нмL), and the return anomaly variables. The regression coefficients for the sample period of 1970/07-2008/06 are first corrected using procedures described in the Internet Appendix and averaged across time. T-values (in parentheses) are computed using the FamaMacBeth procedure and the Newey-West (1987) formula with a lag of 36. Log-transformations are applied to Size and BM. The option adjusted variables are constructed as the residuals from regressing the raw variables with independent variables of BM and ROA (excluding Ivol). There are on average 2,087 stocks each month in our full sample.

\begin{tabular}{|c|c|c|c|c|c|c|c|c|c|c|c|}
\hline & Const. & Beta & Beta_MKT & Beta_smB & Beta_HML & Ast_gw & Inv & Lret & Sue & Momt & Adj $R^{2}$ \\
\hline Model 1 & $\begin{array}{c}0.0027 \\
(2.51)\end{array}$ & $\begin{array}{c}0.0035 \\
(2.19)\end{array}$ & - & - & - & - & - & - & - & - & $1.90 \%$ \\
\hline Model 2 & $\begin{array}{c}0.0028 \\
(2.60)\end{array}$ & $\begin{array}{c}0.0043 \\
(2.68)\end{array}$ & - & - & - & $\begin{array}{c}-0.0058 \\
(-3.50)\end{array}$ & - & - & - & - & $2.03 \%$ \\
\hline Model 3 & $\begin{array}{c}0.0028 \\
(2.58)\end{array}$ & $\begin{array}{c}0.0041 \\
(2.55)\end{array}$ & - & - & - & - & $\begin{array}{c}-0.0068 \\
(-2.04)\end{array}$ & - & - & - & $2.02 \%$ \\
\hline Model 4 & $\begin{array}{c}0.0026 \\
(2.77)\end{array}$ & $\begin{array}{c}0.0040 \\
(2.43)\end{array}$ & - & - & - & - & - & $\begin{array}{c}-0.0006 \\
(-1.44)\end{array}$ & - & - & $2.02 \%$ \\
\hline Model 5 & $\begin{array}{c}0.0023 \\
(2.26)\end{array}$ & $\begin{array}{c}0.0030 \\
(1.88)\end{array}$ & - & - & - & - & - & - & $\begin{array}{c}0.0015 \\
(8.73)\end{array}$ & - & $2.08 \%$ \\
\hline Model 6 & $\begin{array}{c}0.0019 \\
(2.11)\end{array}$ & $\begin{array}{c}0.0025 \\
(1.74)\end{array}$ & - & - & - & - & - & - & - & $\begin{array}{c}0.0080 \\
(6.89)\end{array}$ & $2.92 \%$ \\
\hline Model 7 & $\begin{array}{c}0.0016 \\
(2.32)\end{array}$ & - & $\begin{array}{l}0.0043 \\
(2.74)\end{array}$ & $\begin{array}{c}0.0012 \\
(0.83)\end{array}$ & $\begin{array}{c}0.0032 \\
(1.99)\end{array}$ & - & - & - & - & - & $1.34 \%$ \\
\hline Model 8 & $\begin{array}{l}0.0017 \\
(2.43)\end{array}$ & - & $\begin{array}{c}0.0048 \\
(3.12)\end{array}$ & $\begin{array}{c}0.0014 \\
(0.91)\end{array}$ & $\begin{array}{c}0.0029 \\
(1.83)\end{array}$ & $\begin{array}{c}-0.0043 \\
(-2.78)\end{array}$ & - & - & - & - & $1.51 \%$ \\
\hline Model 9 & $\begin{array}{c}0.0017 \\
(2.41)\end{array}$ & - & $\begin{array}{c}0.0047 \\
(3.02)\end{array}$ & $\begin{array}{c}0.0014 \\
(0.96)\end{array}$ & $\begin{array}{c}0.0029 \\
(1.83)\end{array}$ & - & $\begin{array}{c}-0.0057 \\
(-2.13)\end{array}$ & - & - & - & $1.47 \%$ \\
\hline Model 10 & $\begin{array}{c}0.0016 \\
(2.57)\end{array}$ & - & $\begin{array}{c}0.0047 \\
(3.04)\end{array}$ & $\begin{array}{c}0.0011 \\
(0.75)\end{array}$ & $\begin{array}{c}0.0030 \\
(1.87)\end{array}$ & - & - & $\begin{array}{l}-0.0007 \\
(-1.88)\end{array}$ & - & - & $1.52 \%$ \\
\hline Model 11 & $\begin{array}{c}0.0013 \\
(1.98)\end{array}$ & - & $\begin{array}{c}0.0037 \\
(2.33)\end{array}$ & $\begin{array}{c}0.0013 \\
(0.88)\end{array}$ & $\begin{array}{c}0.0031 \\
(1.98)\end{array}$ & - & - & - & $\begin{array}{c}0.0013 \\
(8.57)\end{array}$ & - & $1.50 \%$ \\
\hline Model 12 & $\begin{array}{c}0.0012 \\
(1.84)\end{array}$ & - & $\begin{array}{c}0.0030 \\
(1.97)\end{array}$ & $\begin{array}{c}0.0016 \\
(1.00)\end{array}$ & $\begin{array}{c}0.0035 \\
(1.81)\end{array}$ & - & - & - & - & $\begin{array}{c}0.0051 \\
(2.76)\end{array}$ & $2.06 \%$ \\
\hline
\end{tabular}




\section{Table B2: Bias-Corrected Cross-Sectional Regression with Real Option Adjustment: Full Sample}

The dependent variable is option adjusted monthly excess returns; independent variables are beta, betas of Fama-French three-factor (Beta_mкт, Beta_sмв, and Beta_нмL), and the return anomaly variables. The regression coefficients for the sample period of 1970/07-2008/06 are first corrected using procedures described in the Internet Appendix and averaged across time. T-values (in parentheses) are computed using the FamaMacBeth procedure and the Newey-West (1987) formula with a lag of 36. Log-transformations are applied to Size and BM. The option adjusted variables are constructed as the residuals from regressing the raw variables with independent variables of Ivol and ROA (excluding BM). There are on average 2,087 stocks each month in our full sample.

\begin{tabular}{|c|c|c|c|c|c|c|c|c|c|c|c|}
\hline & Const. & Beta & Beta_MKT & Beta_smB & Beta_HML & Ast_gw & Inv & Lret & Sue & Momt & Adj $R^{2}$ \\
\hline Model 1 & $\begin{array}{c}0.0027 \\
(2.93)\end{array}$ & $\begin{array}{c}0.0050 \\
(3.22)\end{array}$ & - & - & - & - & - & - & - & - & $1.54 \%$ \\
\hline Model 2 & $\begin{array}{c}0.0028 \\
(3.02)\end{array}$ & $\begin{array}{c}0.0061 \\
(3.93)\end{array}$ & - & - & - & $\begin{array}{c}-0.0082 \\
(-3.80)\end{array}$ & - & - & - & - & $1.76 \%$ \\
\hline Model 3 & $\begin{array}{c}0.0028 \\
(3.01)\end{array}$ & $\begin{array}{c}0.0058 \\
(3.62)\end{array}$ & - & - & - & - & $\begin{array}{c}-0.0090 \\
(-2.35)\end{array}$ & - & - & - & $1.75 \%$ \\
\hline Model 4 & $\begin{array}{c}0.0027 \\
(3.04)\end{array}$ & $\begin{array}{c}0.0059 \\
(3.76)\end{array}$ & - & - & - & - & - & $\begin{array}{c}-0.0013 \\
(-2.45)\end{array}$ & - & - & $1.75 \%$ \\
\hline Model 5 & $\begin{array}{c}0.0026 \\
(2.83)\end{array}$ & $\begin{array}{c}0.0043 \\
(2.74)\end{array}$ & - & - & - & - & - & - & $\begin{array}{c}0.0013 \\
(7.70)\end{array}$ & - & $1.77 \%$ \\
\hline Model 6 & $\begin{array}{c}0.0024 \\
(2.78)\end{array}$ & $\begin{array}{c}0.0037 \\
(2.59)\end{array}$ & - & - & - & - & - & - & - & $\begin{array}{c}0.0082 \\
(7.14)\end{array}$ & $2.56 \%$ \\
\hline Model 7 & $\begin{array}{c}0.0010 \\
(2.51)\end{array}$ & - & $\begin{array}{c}0.0054 \\
(3.60)\end{array}$ & $\begin{array}{c}0.0026 \\
(1.58)\end{array}$ & $\begin{array}{c}0.0048 \\
(2.68)\end{array}$ & - & - & - & - & - & $1.12 \%$ \\
\hline Model 8 & $\begin{array}{l}0.0011 \\
(2.70)\end{array}$ & - & $\begin{array}{c}0.0061 \\
(4.16)\end{array}$ & $\begin{array}{c}0.0027 \\
(1.67)\end{array}$ & $\begin{array}{c}0.0044 \\
(2.49)\end{array}$ & $\begin{array}{c}-0.0055 \\
(-3.60)\end{array}$ & - & - & - & - & $1.25 \%$ \\
\hline Model 9 & $\begin{array}{c}0.0011 \\
(2.65)\end{array}$ & - & $\begin{array}{c}0.0059 \\
(3.96)\end{array}$ & $\begin{array}{c}0.0027 \\
(1.69)\end{array}$ & $\begin{array}{c}0.0044 \\
(2.50)\end{array}$ & - & $\begin{array}{c}-0.0064 \\
(-2.46)\end{array}$ & - & - & - & $1.34 \%$ \\
\hline Model 10 & $\begin{array}{c}0.0011 \\
(2.78)\end{array}$ & - & $\begin{array}{c}0.0061 \\
(4.13)\end{array}$ & $\begin{array}{c}0.0026 \\
(1.60)\end{array}$ & $\begin{array}{c}0.0043 \\
(2.49)\end{array}$ & - & - & $\begin{array}{c}-0.0010 \\
(-2.82)\end{array}$ & - & - & $1.38 \%$ \\
\hline Model 11 & $\begin{array}{c}0.0009 \\
(2.24)\end{array}$ & - & $\begin{array}{c}0.0048 \\
(3.12)\end{array}$ & $\begin{array}{c}0.0026 \\
(1.60)\end{array}$ & $\begin{array}{c}0.0049 \\
(2.73)\end{array}$ & - & - & - & $\begin{array}{c}0.0011 \\
(6.95)\end{array}$ & - & $1.44 \%$ \\
\hline Model 12 & $\begin{array}{c}0.0008 \\
(2.08)\end{array}$ & - & $\begin{array}{c}0.0043 \\
(2.93)\end{array}$ & $\begin{array}{c}0.0027 \\
(1.75)\end{array}$ & $\begin{array}{c}0.0050 \\
(2.84)\end{array}$ & - & - & - & - & $\begin{array}{c}0.0048 \\
(3.63)\end{array}$ & $1.89 \%$ \\
\hline
\end{tabular}


Table B3: Bias-Corrected Cross-Sectional Regression with Real Option Adjustment: Full Sample

The dependent variable is option adjusted monthly excess returns; independent variables are beta, betas of Fama-French three-factor (Beta_mкт, Beta_sмв, and Beta_нмL), and the return anomaly variables. The regression coefficients for the sample period of 1970/07-2008/06 are first corrected using procedures described in the Internet Appendix and averaged across time. T-values (in parentheses) are computed using the FamaMacBeth procedure and the Newey-West (1987) formula with a lag of 36. Log-transformations are applied to Size and BM. The option adjusted variables are constructed as the residuals from regressing the raw variables with independent variables of Ivol and BM (excluding ROA). There are on average 2,087 stocks each month in our full sample.

\begin{tabular}{|c|c|c|c|c|c|c|c|c|c|c|c|}
\hline & Const. & Beta & Beta_MKT & Beta_smB & Beta_HML & Ast_gw & Inv & Lret & Sue & Momt & Adj $\mathrm{R}^{2}$ \\
\hline Model 1 & $\begin{array}{c}0.0015 \\
(2.46)\end{array}$ & $\begin{array}{c}0.0049 \\
(3.08)\end{array}$ & - & - & - & - & - & - & - & - & $1.81 \%$ \\
\hline Model 2 & $\begin{array}{c}0.0015 \\
(2.56)\end{array}$ & $\begin{array}{c}0.0057 \\
(3.69)\end{array}$ & - & - & - & $\begin{array}{c}-0.0056 \\
(-3.27)\end{array}$ & - & - & - & - & $1.98 \%$ \\
\hline Model 3 & $\begin{array}{c}0.0015 \\
(2.53)\end{array}$ & $\begin{array}{c}0.0054 \\
(3.40)\end{array}$ & - & - & - & - & $\begin{array}{c}-0.0055 \\
(-1.59)\end{array}$ & - & - & - & $1.98 \%$ \\
\hline Model 4 & $\begin{array}{c}0.0013 \\
(2.66)\end{array}$ & $\begin{array}{c}0.0052 \\
(3.25)\end{array}$ & - & - & - & - & - & $\begin{array}{c}-0.0003 \\
(-0.82)\end{array}$ & - & - & $1.98 \%$ \\
\hline Model 5 & $\begin{array}{c}0.0011 \\
(2.11)\end{array}$ & $\begin{array}{c}0.0040 \\
(2.48)\end{array}$ & - & - & - & - & - & - & $\begin{array}{l}0.0021 \\
(10.31)\end{array}$ & - & $2.05 \%$ \\
\hline Model 6 & $\begin{array}{c}0.0010 \\
(1.95)\end{array}$ & $\begin{array}{c}0.0036 \\
(2.41)\end{array}$ & - & - & - & - & - & - & - & $\begin{array}{c}0.0092 \\
(7.99)\end{array}$ & $2.86 \%$ \\
\hline Model 7 & $\begin{array}{c}0.0007 \\
(2.13)\end{array}$ & - & $\begin{array}{c}0.0051 \\
(3.30)\end{array}$ & $\begin{array}{c}0.0022 \\
(1.35)\end{array}$ & $\begin{array}{c}0.0028 \\
(1.67)\end{array}$ & - & - & - & - & - & $1.22 \%$ \\
\hline Model 8 & $\begin{array}{c}0.0008 \\
(2.31)\end{array}$ & - & $\begin{array}{c}0.0056 \\
(3.79)\end{array}$ & $\begin{array}{c}0.0023 \\
(1.44)\end{array}$ & $\begin{array}{c}0.0025 \\
(1.51)\end{array}$ & $\begin{array}{c}-0.0043 \\
(-2.95)\end{array}$ & - & - & - & - & $1.31 \%$ \\
\hline Model 9 & $\begin{array}{c}0.0008 \\
(2.25)\end{array}$ & - & $\begin{array}{c}0.0055 \\
(3.59)\end{array}$ & $\begin{array}{c}0.0023 \\
(1.45)\end{array}$ & $\begin{array}{c}0.0025 \\
(1.51)\end{array}$ & - & $\begin{array}{c}-0.0048 \\
(-1.84)\end{array}$ & - & - & - & $1.41 \%$ \\
\hline Model 10 & $\begin{array}{c}0.0007 \\
(2.26)\end{array}$ & - & $\begin{array}{c}0.0055 \\
(3.58)\end{array}$ & $\begin{array}{c}0.0021 \\
(1.28)\end{array}$ & $\begin{array}{c}0.0025 \\
(1.52)\end{array}$ & - & - & $\begin{array}{c}-0.0004 \\
(-1.22)\end{array}$ & - & - & $1.30 \%$ \\
\hline Model 11 & $\begin{array}{c}0.0005 \\
(1.51)\end{array}$ & - & $\begin{array}{c}0.0042 \\
(2.62)\end{array}$ & $\begin{array}{c}0.0022 \\
(1.37)\end{array}$ & $\begin{array}{c}0.0027 \\
(1.68)\end{array}$ & - & - & - & $\begin{array}{l}0.0018 \\
(10.03)\end{array}$ & - & $1.56 \%$ \\
\hline Model 12 & $\begin{array}{c}0.0005 \\
(1.56)\end{array}$ & - & $\begin{array}{c}0.0036 \\
(2.30)\end{array}$ & $\begin{array}{c}0.0028 \\
(1.59)\end{array}$ & $\begin{array}{c}0.0034 \\
(1.49)\end{array}$ & - & - & - & - & $\begin{array}{c}0.0060 \\
(2.81)\end{array}$ & $1.81 \%$ \\
\hline
\end{tabular}


Table B4: Bias-Corrected Cross-Sectional Regression with Real Option Adjustment: Subsample

Cross-sectional regression analysis is conducted on the subsample of stocks after excluding stocks whose betas are likely estimated with large errors. The dependent variable is the optioned-adjusted monthly excess returns; independent variables are beta, betas of Fama-French three-factor (Beta_мкт, Beta_sмв, and Beta_нмL) and the return anomaly variables. The regression coefficients for the sample period of 1970/07-2008/06 are first corrected using procedures described in the Internet Appendix and averaged across time. T-values (in parentheses) are computed using the Fama-MacBeth procedure and the Newey-West (1987) formula with a lag of 36. Log-transformations are applied to Size and BM. The option adjusted variables are constructed as the residuals from regressing the raw variables with independent variables of BM and ROA (excluding Ivol). There are on average 1,783 stocks each month in our subsample.

\begin{tabular}{|c|c|c|c|c|c|c|c|c|c|c|c|}
\hline & Const. & Beta & Beta_MKT & Beta_smB & Beta_HML & Ast_gw & Inv & Lret & Sue & Momt & $\operatorname{Adj} R^{2}$ \\
\hline Model 1 & $\begin{array}{c}0.0021 \\
(1.73)\end{array}$ & $\begin{array}{c}0.0044 \\
(2.33)\end{array}$ & - & - & - & - & - & - & - & - & $1.48 \%$ \\
\hline Model 2 & $\begin{array}{l}0.0020 \\
(1.71)\end{array}$ & $\begin{array}{l}0.0053 \\
(2.76)\end{array}$ & - & - & - & $\begin{array}{c}-0.0052 \\
(-3.23)\end{array}$ & - & - & - & - & $1.65 \%$ \\
\hline Model 3 & $\begin{array}{l}0.0020 \\
(1.74)\end{array}$ & $\begin{array}{l}0.0051 \\
(2.64)\end{array}$ & - & - & - & - & $\begin{array}{c}-0.0064 \\
(-1.74)\end{array}$ & - & - & - & $1.65 \%$ \\
\hline Model 4 & $\begin{array}{c}0.0019 \\
(1.77)\end{array}$ & $\begin{array}{l}0.0050 \\
(2.57)\end{array}$ & - & - & - & - & - & $\begin{array}{c}-0.0004 \\
(-1.29)\end{array}$ & - & - & $1.65 \%$ \\
\hline Model 5 & $\begin{array}{l}0.0018 \\
(1.57)\end{array}$ & $\begin{array}{l}0.0038 \\
(1.97)\end{array}$ & - & - & - & - & - & - & $\begin{array}{c}0.0015 \\
(8.02)\end{array}$ & - & $1.73 \%$ \\
\hline Model 6 & $\begin{array}{c}0.0014 \\
(1.48)\end{array}$ & $\begin{array}{c}0.0030 \\
(1.78)\end{array}$ & - & - & - & - & - & - & - & $\begin{array}{c}0.0087 \\
(7.81)\end{array}$ & $2.64 \%$ \\
\hline Model 7 & $\begin{array}{c}0.0009 \\
(1.29)\end{array}$ & - & $\begin{array}{l}0.0053 \\
(2.70)\end{array}$ & $\begin{array}{l}0.0011 \\
(0.64)\end{array}$ & $\begin{array}{c}0.0028 \\
(1.43)\end{array}$ & - & - & - & - & - & $0.88 \%$ \\
\hline Model 8 & $\begin{array}{c}0.0009 \\
(1.31)\end{array}$ & - & $\begin{array}{l}0.0058 \\
(2.95)\end{array}$ & $\begin{array}{c}0.0012 \\
(0.71)\end{array}$ & $\begin{array}{c}0.0026 \\
(1.32)\end{array}$ & $\begin{array}{c}-0.0037 \\
(-2.49)\end{array}$ & - & - & - & - & $0.98 \%$ \\
\hline Model 9 & $\begin{array}{c}0.0010 \\
(1.41)\end{array}$ & - & $\begin{array}{c}0.0057 \\
(2.84)\end{array}$ & $\begin{array}{c}0.0012 \\
(0.76)\end{array}$ & $\begin{array}{c}0.0025 \\
(1.27)\end{array}$ & - & $\begin{array}{c}-0.0052 \\
(-1.71)\end{array}$ & - & - & - & $1.05 \%$ \\
\hline Model 10 & $\begin{array}{c}0.0009 \\
(1.34)\end{array}$ & - & $\begin{array}{l}0.0059 \\
(3.02)\end{array}$ & $\begin{array}{l}0.0009 \\
(0.57)\end{array}$ & $\begin{array}{c}0.0025 \\
(1.26)\end{array}$ & - & - & $\begin{array}{l}-0.0006 \\
(-2.07)\end{array}$ & - & - & $0.99 \%$ \\
\hline Model 11 & $\begin{array}{c}0.0007 \\
(1.09)\end{array}$ & - & $\begin{array}{c}0.0045 \\
(2.30)\end{array}$ & $\begin{array}{c}0.0012 \\
(0.70)\end{array}$ & $\begin{array}{c}0.0027 \\
(1.41)\end{array}$ & - & - & - & $\begin{array}{c}0.0012 \\
(7.31)\end{array}$ & - & $1.10 \%$ \\
\hline Model 12 & $\begin{array}{l}0.0007 \\
(1.13)\end{array}$ & - & $\begin{array}{l}0.0057 \\
(2.51)\end{array}$ & $\begin{array}{l}-0.0019 \\
(-0.72)\end{array}$ & $\begin{array}{c}-0.0024 \\
(-0.49)\end{array}$ & - & - & - & - & $\begin{array}{l}0.0063 \\
(2.55)\end{array}$ & $1.59 \%$ \\
\hline
\end{tabular}


Table B5: Bias-Corrected Cross-Sectional Regression with Real Option Adjustment: Subsample

Cross-sectional regression analysis is conducted on the subsample of stocks after excluding stocks whose betas are likely estimated with large errors. The dependent variable is the optioned-adjusted monthly excess returns; independent variables are beta, betas of Fama-French three-factor (Beta_мкт, Beta_sмв, and Beta_нмц) and the return anomaly variables. The regression coefficients for the sample period of 1970/07-2008/06 are first corrected using procedures described in the Internet Appendix and averaged across time. T-values (in parentheses) are computed using the Fama-MacBeth procedure and the Newey-West (1987) formula with a lag of 36. Log-transformations are applied to Size and BM. The option adjusted variables are constructed as the residuals from regressing the raw variables with independent variables of Ivol and ROA (excluding BM). There are on average 1,783 stocks each month in our subsample.

\begin{tabular}{|c|c|c|c|c|c|c|c|c|c|c|c|}
\hline & Const. & Beta & Beta_MKT & Beta_smB & Beta_HML & Ast_gw & Inv & Lret & Sue & Momt & Adj $R^{2}$ \\
\hline Model 1 & $\begin{array}{l}0.0015 \\
(1.73)\end{array}$ & $\begin{array}{c}0.0071 \\
(3.91)\end{array}$ & - & - & - & - & - & - & - & - & $1.26 \%$ \\
\hline Model 2 & $\begin{array}{c}0.0014 \\
(1.55)\end{array}$ & $\begin{array}{c}0.0084 \\
(4.50)\end{array}$ & - & - & - & $\begin{array}{c}-0.0083 \\
(-3.56)\end{array}$ & - & - & - & - & $1.54 \%$ \\
\hline Model 3 & $\begin{array}{c}0.0014 \\
(1.63)\end{array}$ & $\begin{array}{c}0.0081 \\
(4.17)\end{array}$ & - & - & - & - & $\begin{array}{c}-0.0098 \\
(-2.24)\end{array}$ & - & - & - & $1.48 \%$ \\
\hline Model 4 & $\begin{array}{c}0.0012 \\
(1.51)\end{array}$ & $\begin{array}{c}0.0083 \\
(4.48)\end{array}$ & - & - & - & - & - & $\begin{array}{r}-0.0013 \\
(-2.70)\end{array}$ & - & - & $1.48 \%$ \\
\hline Model 5 & $\begin{array}{c}0.0014 \\
(1.75)\end{array}$ & $\begin{array}{c}0.0063 \\
(3.40)\end{array}$ & - & - & - & - & - & - & $\begin{array}{c}0.0012 \\
(6.86)\end{array}$ & - & $1.52 \%$ \\
\hline Model 6 & $\begin{array}{c}0.0014 \\
(1.88)\end{array}$ & $\begin{array}{c}0.0053 \\
(3.21)\end{array}$ & - & - & - & - & - & - & - & $\begin{array}{c}0.0087 \\
(8.02)\end{array}$ & $2.30 \%$ \\
\hline Model 7 & $\begin{array}{c}0.0001 \\
(0.15)\end{array}$ & - & $\begin{array}{c}0.0068 \\
(3.24)\end{array}$ & $\begin{array}{c}0.0028 \\
(1.55)\end{array}$ & $\begin{array}{c}0.0044 \\
(1.96)\end{array}$ & - & - & - & - & - & $0.65 \%$ \\
\hline Model 8 & $\begin{array}{c}0.0000 \\
(0.09)\end{array}$ & - & $\begin{array}{c}0.0076 \\
(3.52)\end{array}$ & $\begin{array}{c}0.0029 \\
(1.63)\end{array}$ & $\begin{array}{c}0.0039 \\
(1.75)\end{array}$ & $\begin{array}{c}-0.0052 \\
(-3.64)\end{array}$ & - & - & - & - & $0.73 \%$ \\
\hline Model 9 & $\begin{array}{c}0.0001 \\
(0.16)\end{array}$ & - & $\begin{array}{c}0.0074 \\
(3.38)\end{array}$ & $\begin{array}{c}0.0030 \\
(1.67)\end{array}$ & $\begin{array}{c}0.0039 \\
(1.76)\end{array}$ & - & $\begin{array}{c}-0.0064 \\
(-2.06)\end{array}$ & - & - & - & $0.76 \%$ \\
\hline Model 10 & $\begin{array}{c}0.0000 \\
(0.10)\end{array}$ & - & $\begin{array}{c}0.0077 \\
(3.55)\end{array}$ & $\begin{array}{c}0.0029 \\
(1.64)\end{array}$ & $\begin{array}{c}0.0038 \\
(1.78)\end{array}$ & - & - & $\begin{array}{r}-0.0009 \\
(-3.50)\end{array}$ & - & - & $0.84 \%$ \\
\hline Model 11 & $\begin{array}{c}0.0000 \\
(0.03)\end{array}$ & - & $\begin{array}{c}0.0062 \\
(2.84)\end{array}$ & $\begin{array}{c}0.0028 \\
(1.57)\end{array}$ & $\begin{array}{c}0.0044 \\
(2.00)\end{array}$ & - & - & - & $\begin{array}{c}0.0010 \\
(5.03)\end{array}$ & - & $0.84 \%$ \\
\hline Model 12 & $\begin{array}{c}0.0001 \\
(0.20)\end{array}$ & - & $\begin{array}{c}0.0052 \\
(2.53)\end{array}$ & $\begin{array}{c}0.0031 \\
(1.77)\end{array}$ & $\begin{array}{c}0.0049 \\
(2.22)\end{array}$ & - & - & - & - & $\begin{array}{c}0.0052 \\
(3.85)\end{array}$ & $1.50 \%$ \\
\hline
\end{tabular}


Table B6: Bias-Corrected Cross-Sectional Regression with Real Option Adjustment: Subsample

Cross-sectional regression analysis is conducted on the subsample of stocks after excluding stocks whose betas are likely estimated with large errors. The dependent variable is the optioned-adjusted monthly excess returns; independent variables are beta, betas of Fama-French three-factor (Beta_мкт, Beta_sмв, and Beta_нмц) and the return anomaly variables. The regression coefficients for the sample period of 1970/07-2008/06 are first corrected using procedures described in the Internet Appendix and averaged across time. T-values (in parentheses) are computed using the Fama-MacBeth procedure and the Newey-West (1987) formula with a lag of 36. Log-transformations are applied to Size and BM. The option adjusted variables are constructed as the residuals from regressing the raw variables with independent variables of Ivol and BM (excluding ROA). There are on average 1,783 stocks each month in our subsample.

\begin{tabular}{|c|c|c|c|c|c|c|c|c|c|c|c|}
\hline & Const. & Beta & Beta_MKT & Beta_smB & Beta_HML & Ast_gw & Inv & Lret & Sue & Momt & Adj $R^{2}$ \\
\hline Model 1 & $\begin{array}{c}0.0009 \\
(1.66)\end{array}$ & $\begin{array}{c}0.0061 \\
(3.50)\end{array}$ & - & - & - & - & - & - & - & - & $1.69 \%$ \\
\hline Model 2 & $\begin{array}{l}0.0009 \\
(1.62)\end{array}$ & $\begin{array}{l}0.0070 \\
(4.04)\end{array}$ & - & - & - & $\begin{array}{c}-0.0053 \\
(-3.16)\end{array}$ & - & - & - & - & $1.85 \%$ \\
\hline Model 3 & $\begin{array}{l}0.0009 \\
(1.65)\end{array}$ & $\begin{array}{l}0.0068 \\
(3.74)\end{array}$ & - & - & - & - & $\begin{array}{c}-0.0055 \\
(-1.43)\end{array}$ & - & - & - & $1.81 \%$ \\
\hline Model 4 & $\begin{array}{c}0.0008 \\
(1.65)\end{array}$ & $\begin{array}{l}0.0066 \\
(3.67)\end{array}$ & - & - & - & - & - & $\begin{array}{c}-0.0003 \\
(-0.81)\end{array}$ & - & - & $1.81 \%$ \\
\hline Model 5 & $\begin{array}{l}0.0007 \\
(1.45)\end{array}$ & $\begin{array}{l}0.0051 \\
(2.83)\end{array}$ & - & - & - & - & - & - & $\begin{array}{c}0.0019 \\
(9.13)\end{array}$ & - & $1.96 \%$ \\
\hline Model 6 & $\begin{array}{c}0.0006 \\
(1.31)\end{array}$ & $\begin{array}{c}0.0044 \\
(2.75)\end{array}$ & - & - & - & - & - & - & - & $\begin{array}{c}0.0095 \\
(8.57)\end{array}$ & $2.70 \%$ \\
\hline Model 7 & $\begin{array}{c}0.0003 \\
(0.88)\end{array}$ & - & $\begin{array}{l}0.0060 \\
(3.21)\end{array}$ & $\begin{array}{l}0.0023 \\
(1.30)\end{array}$ & $\begin{array}{c}0.0022 \\
(1.10)\end{array}$ & - & - & - & - & - & $0.88 \%$ \\
\hline Model 8 & $\begin{array}{c}0.0003 \\
(0.91)\end{array}$ & - & $\begin{array}{c}0.0066 \\
(3.51)\end{array}$ & $\begin{array}{c}0.0024 \\
(1.40)\end{array}$ & $\begin{array}{c}0.0020 \\
(0.98)\end{array}$ & $\begin{array}{l}-0.0038 \\
(-2.86)\end{array}$ & - & - & - & - & $1.01 \%$ \\
\hline Model 9 & $\begin{array}{c}0.0003 \\
(0.99)\end{array}$ & - & $\begin{array}{l}0.0064 \\
(3.34)\end{array}$ & $\begin{array}{c}0.0025 \\
(1.42)\end{array}$ & $\begin{array}{c}0.0019 \\
(0.94)\end{array}$ & - & $\begin{array}{c}-0.0044 \\
(-1.47)\end{array}$ & - & - & - & $0.97 \%$ \\
\hline Model 10 & $\begin{array}{l}0.0002 \\
(0.85)\end{array}$ & - & $\begin{array}{l}0.0065 \\
(3.47)\end{array}$ & $\begin{array}{c}0.0022 \\
(1.26)\end{array}$ & $\begin{array}{c}0.0018 \\
(0.91)\end{array}$ & - & - & $\begin{array}{c}-0.0004 \\
(-1.28)\end{array}$ & - & - & $1.01 \%$ \\
\hline Model 11 & $\begin{array}{l}0.0001 \\
(0.45)\end{array}$ & - & $\begin{array}{c}0.0050 \\
(2.62)\end{array}$ & $\begin{array}{c}0.0023 \\
(1.32)\end{array}$ & $\begin{array}{c}0.0021 \\
(1.08)\end{array}$ & - & - & - & $\begin{array}{c}0.0017 \\
(8.20)\end{array}$ & - & $1.15 \%$ \\
\hline Model 12 & $\begin{array}{l}0.0001 \\
(0.32)\end{array}$ & - & $\begin{array}{l}0.0052 \\
(3.16)\end{array}$ & $\begin{array}{l}0.0013 \\
(0.70)\end{array}$ & $\begin{array}{c}-0.0013 \\
(-0.38)\end{array}$ & - & - & - & - & $\begin{array}{c}0.0100 \\
(5.11)\end{array}$ & $1.41 \%$ \\
\hline
\end{tabular}


